\title{
Sulcando os mares: Um historiador do império português enfrenta a "Atlantic History"
}

\section{A.J.R. RUSSELL-WOOD •}

\begin{abstract}
Resumo: Esta contribuição para a história tem duas dimensões. A que predomina é a historiográfica: a gênese e evolução da "Atlantic history", as suas características, ênfases e metodologia, e como diverge da história consciente de um quadro imperial. A segunda é um praticum: quer dizer, a minha tentativa em conceitualizar e organizar um artigo sobre "o Atlântico luso-afro-brasileiro" no período de cerca 1660 até cerca de 1760, segundo o que entendo ser as normas e preceitos do "Atlantic history". Fruto de tal experiência, concluo com avaliação em respeito dos prós e contras, do "Atlantic history", em comparação com outras historiografias e faço observações a respeito do seu potencial para abrir novos ramos de pesquisa para a História do Brasil Colonial.
\end{abstract}

Palavras-chave: Historiografias; Atlântico luso-afro-brasileiro; Atlantic history.

\section{Introdução: modos de escrever história em debate}

Uma historiografia mais antiga, dos impérios europeus ultramarinos, tendia a manter o foco nas conquistas e nos atos de possessão, no povoamento e na colonização, no comércio, na evangelização, e no processo de governança. Essa historiografia nunca questionou que as habilidades técnicas, o conhecimento da tecnologia, a inovação e a criatividade fossem exclusivamente europeus. As populações autóctones eram vistas

\footnotetext{
- Professor Doutor - Departamento de História - Universidade John Hopkins - Baltimore - Maryland - 21218 - Estados Unidos. E-mail: russwood@jhu.edu
} 
mais como receptoras passivas do que proativas. Essas histórias foram geralmente escritas a partir de uma perspectiva metropolitana e a única função dos colonos e a razão de ser das colônias era prover matérias-primas, ouro e prata, e pedras preciosas para a metrópole. Esta "história diplomática", baseada nos arquivos governamentais, tratou dos indivíduos das altas camadas sociais, de poder e autoridade no governo das nações, e foi notável pelas suas atitudes elitistas. No caso da historiografia brasileira, já os historiadores Capistrano de Abreu (1853-1927) e Sérgio Buarque de Holanda (1902-82) adotaram perspectivas de homens da colônia. O historiador marxista Caio Prado Júnior (1907-90) tratou da colonização portuguesa, mas insistiu em indicar outros processos, próprios da colônia: formação de um mercado interno de alimentos: criação de gado, de suínos e produção de queijo no sul de Minas Gerais.

Nas décadas de 60 e 70 do século $X X$, as perspectivas dos historiadores europeus e estadunidenses mudaram e passaram a incluir outras perspectivas não-européias, a reconhecer $o$ multiculturalismo, e a dar a devida importância ao papel da mulher. Houve uma outra aproximação subsequente à história social e cultural que pode ser caracterizada como "uma perspectiva de baixo para cima", na qual o foco foi mais popular e enfatizou as atividades sociais, políticas e econômicas de indivíduos e coletividades das camadas baixas ou médias e daquele "povo sem voz".

No caso dos impérios de reinos ou estados europeus, raramente houve nesta historiografia uma dimensão comparativa entre impérios, e mesmo nos exemplos dos impérios como o britânico, o holandês, o português ou o francês, que estiveram em dois hemisférios, em vez de se aproveitar de seu potencial para estudá-los globalmente, eles têm sido divididos entre Oriente e Ocidente ${ }^{1}$. Grande parte da historiografia tem sucumbido à fragmentação disciplinar em sub-campos da história: história institucional; história das burocracias; estudos prosopográficos dos burocratas dos impérios. No caso do império português, há até mesmo uma 
SULCANDO OS MARES: UM HISTORIADOR DO IMPÉRIO PORTUGUÊS...

grande ausência do gênero de história que é mais popular com o público: a saber, biografias.

Já no início da década de 1970 houve uma iniciativa da parte de um grupo de historiadores da Universidade Johns Hopkins, liderados por Jack P. Greene, que lançaram uma iniciativa com antropólogos e adotaram o Atlântico como campo de pesquisa caracterizada por metodologias interdisciplinárias e uma perspectiva comparativa. Procuraram fugir do molde imperial ou nacionalista para atravessar divisas e fronteiras, para estudar os movimentos das pessoas, de animais, de plantas e mercadorias numa escala não apenas Atlântica mas global, para reconstituir o ir e vir de idéias, estilos, modas e artes. A intenção foi reunir estudiosos de várias disciplinas que contribuíram para a criação de uma nova perspectiva e uma aproximação original à riqueza de facetas do Atlântico e da interconectividade dos povos nos continentes banhados pelas suas ondas ${ }^{2}$. Inicialmente, a nossa intenção foi apenas oferecer uma nova perspectiva sobre os países, continentes, povos, culturas, e instituições ao redor do oceano. Esta iniciativa despertou a atenção de outros acadêmicos: economistas, geógrafos, psicólogos sociais e sociólogos. A imprensa universitária lançou monografias por historiadores e antropólogos que faziam parte de uma série chamada "Atlantic History and Culture". O conceito de "Atlantic History" ia sendo aceito pelos estudiosos de múltiplas disciplinas como valioso campo de pesquisa e contexto para organizar informações. Compartilharam da perspectiva original e foram amplificando-a e reformulando-a. Passaram duas décadas. Começou a institucionalização: criação de programas de Estudos Atlânticos, sobretudo nos Estados Unidos, mas também na Europa e mesmo na Austrália; inauguração de cursos a todos os níveis, inclusive de pós-graduação e doutoramento; e cátedras dedicadas à História do Atlântico. Muitos estudiosos foram incentivados a considerar novos campos de pesquisa, a revisitar campos já trabalhados, e a reconhecer novos horizontes. Para outros, a "Atlantic History" ia sendo consagrada como um discreto ramo de estudos, debaixo da panóplia ampla da disciplina de história. 
Nestes últimos dez anos, houve uma verdadeira onda de monografias cujos títulos incluem a palavra "Atlântico", a maior parte da autoria de historiadores.

Este novo ramo de história deve a sua popularidade (alguns dizem "modista") e a rapidez de aceitação de um número crescente de aderentes em parte ao fato de ser concebido e promovido por historiadores dos mais eminentes na constelação acadêmica. Assim, o meu ponto de partida será a consideração das suas definições. Bernard Bailyn, professor da universidade de Harvard, ofereceu a seguinte: "durante o período moderno (ca. 1500-1800), a Europa ocidental, a África ocidental, e as Américas foram bastante integradas em vários aspectos para merecerem ser considerados como uma única entidade" ${ }^{\prime 3}$. Por sua parte, recentemente Jack P. Greene definiu este novo ramo da História assim:

A Atlantic History é um constructo analítico e uma categoria explícita de análise histórica que os historiadores têm delineado para ajudá-los na organização dos estudos de algumas das marchas dos acontecimentos da época moderna: o surgimento no século quatorze, e desenvolvimento subsequente da bácia Atlântica como um sítio onde deviam ser localizados várias formas de intercâmbio: demográfico, econômico, social, e cultural inter alia, entre e dentro dos quatro continentes ao redor do Oceano Atlântico —Europa, África, América do Sul, e a América do Norte - e todas as ilhas contíguas a estes continentes e naquele oceano. ${ }^{4}$

O ilustre historiador britânico Sir John Elliott observou que se trata do estudo "da criação, da destrução, e da criação de novo de comunidades como resultado do movimento através e ao redor da bacia do Atlântico, de indivíduos, de mercadorias, de práticas culturais e de valores" 5 .

Como neófito neste novo ramo da história, o meu propósito aqui consiste em submeter um período na história do Atlântico de fala portuguesa a uma análise que reflete os que parecem ser os critérios e características desta "nova" história: um exercício na integração das múltiplas dimensões do mundo Atlântico, uma 
SULCANDO OS MARES: UM HISTORIADOR DO IMPÉRIO PORTUGUÊS...

ênfase sobre aqueles aspectos que ultrapassam/transcendem as fronteiras políticas ou nacionais; as conexões, interconectividade, redes e diásporas que ligam a Europa, as Américas e a África; intercâmbio, seja de indivíduos, de flora e fauna, de mercadorias e produtos, seja de línguas, de culturas, de manifestações de fé, e de costumes e práticas tradicionais; um Atlântico caracterizado pelo movimento, pelo vaivém, e transições, e a vários ritmos de aceleração; e um mundo onde instituições, mesmo reinos, se formam, reformulam-se de um modo distinto, fragmentam-se, apenas para reaparecerem com uma nova configuração. Um conceito inerente a esta história é que nenhuma parte possa existir em isolamento. Um evento epidemia, seca, guerra, fome - em uma parte tem repercussões e ressoa em outras partes. Esta história é quintessencialmente humana - um exame da condição humana, como os indivíduos lutam e vencem, como enfrentam os obstáculos e como aguentam pobreza, fome, opressão, e doença - sem levar em consideração as distinções de pigmentação, de crenças religiosas, de etnicidade, do gênero, e de status social ou econômico. Revela o que os povos à orla do Atlântico têm em comum e onde existem divergências.

\section{O Atlântico luso-afro-brasileiro}

A minha abordagem não será diretamente institucional ou política. Muito do que eu vou descrever ocorreu sem a intervenção direita ou a iniciativa da Coroa portuguesa. A estrutura e o contexto não serão nem imperiais nem institucionais. $\mathrm{Na}$ minha narrativa, a burocracia do Império ocupará um segundo plano ou estará ausente. Várias considerações me levaram a escolher o período que vai desde ca 1660 até ca 1760. Foi um século bastante constante geograficamente, depois dos predatórios holandeses e ocupações em Angola, São Tomé e Príncipe e no Brasil, sendo a 
única perda irremediável aquela da feitoria e Fortaleza de São Jorge da Mina pelos Holandeses em 1637 e subsequentes conquistas de Samá (1640) e Axém (1642), terminando assim uma presença portuguesa na costa do golfo da Guiné. O Atlântico voltou a merecer a atenção da coroa portuguesa, depois de um período na primeira metade do século XVI de obsessão com o Oriente, incentivada pela redução do império português oriental a Goa, Damão, Diu, Bassein, Macao, parte de Timor e algumas fortalezas. Demográficamemte, o centro de gravidade populacional de portugueses ficou nas ilhas do Atlântico e nas colônias portuguesas ao redor do oceano. Este século (ca 1660-ca 1760) testemunhou avanços em movimentos migratórios, de colonização, de urbanização, de atividades comerciais, de agricultura, e de economias de maior diversidade. A primeira metade do século dezoito marcou a idade do ouro e de diamantes no Brasil com repercussões não apenas para as outras colônias mas também para a situação doméstica em Portugal, para as relações entre a metrôpole e o ultramar, e também para as relações entre Portugal e países europeus, sobretudo a Inglaterra e o Vaticano. As resoluções diplomáticas e alianças com Holanda, França e Inglaterra, o fim de hostilidades com a Espanha e a independência de Portugal em 1668 não garantiram a autonomia portuguesa perante pressões econômicas e comerciais da parte da Inglaterra e de outros países europeus que ameaçaram as atividades comerciais portuguesas no Atlântico. A história portuguesa no Atlântico exige ser considerada dentro do contexto internacional, de interações com nações e estados europeus e não europeus, pelo fato de que este Mundo Português no Atlântico sempre foi irrevogavelmente vinculado às regiões e aos mares e oceanos para além do Cabo de Boa Esperança e para além do Estreito de Magalhães ${ }^{6}$.

A esfera de influência portuguesa no Atlântico nesse período se extendia do Sul do Marrocos até Benguela na África, e do Rio Amazonas até o Rio da Prata na América do Sul. As possessões portuguesas tinham os extremos de geodiversidade e de biodiversidade: características físicas, de clima, de 
SULCANDO OS MARES: UM HISTORIADOR DO IMPÉRIO PORTUGUÊS...

atividades sísmicas, de solos e de vegetações. Cada região era sui generis. $\mathrm{Na}$ pior das hipóteses, isso levava a um isolamento comercial e demográfico; na melhor, a cultivos e exportações complementares, à integração em redes comerciais e migratórias maiores e a intercâmbios de pessoas e culturas. A característica dominante era o oceano. O Atlântico desempenhou o papel de estabelecer os ritmos do império, influenciava a governança, as comunicações, o comércio, a migração, os intercâmbios culturais, os movimentos de flora e fauna e até mesmo como os indivíduos se autoidentificavam. Rotas conectavam todos os pontos no Atlântico português e facilitavam o intercâmbio entre a África e a América portuguesas. Os arquipélagos portugueses eram pontos de articulação entre o norte e o sul e entre o leste e o oeste ${ }^{7}$.

O Atlântico sempre foi central para a história de Portugal. A partir do final do século XVII houve intensa atividade de construção de navios em estaleiros particulares no Brasil. Isso se acelerou no século XVIII, com as embarcações para as rotas africanas e européias. Lá pelo final do século, provavelmente, eram construídas mais embarcações em estaleiros brasileiros do que em Portugal. Embarcações para a carreira da Índia também eram construídas em estaleiros reais no Brasil. Em geral, as embarcações para o comércio Atlântico eram agora mais bem construídas, maiores, com mais capacidade, e incorporavam mudanças na enxárxia, nos equipamentos e nas velas ${ }^{8}$. O preço para entrar e fazer parte do comércio Atlântico era muito menor do que para a rota do Cabo. Nenhuma rota no Atlântico excedia três meses de um porto a outro. Isso era um incentivo para indivíduos, consórcios de comerciantes e homens de negócio se encarregarem de construir embarcações relativamente baratas e rápidas. Uma combinação de condições de mercado, oferta e procura, carregamentos mais volumosos, mais transbordos, e uma infraestrutura mais sofisticada - instalações portuárias, modos mais sofisticados e pessoal mais habilitado em estivar, agentes bancários, e seguradoras - contribuíram para o uso ainda mais intenso do Atlântico por Portugal e suas colônias ${ }^{9}$. O tempo e a distância exigiam um custo para os marinheiros e 
suas famílias. As condições a bordo eram parcas e as rações eram pouco adequadas. Os sistemas de vento que variavam sazonalmente e as partidas fora da época expunham as tripulações a ficarem parados nas calmarias saindo de Portugal ou sofrendo severas condições climáticas a caminho de regresso. Os marinheiros estavam frequentemente em más condições quando embarcavam, suscetíveis a doenças, e eram hospitalizados nos portos brasileiros ou em Luanda. Marinheiros deixando o navio no Brasil e a mortalidade a bordo levavam a constantes alterações e a tripulações incompletas. As tripulações incluíam africanos, afro-brasileiros, europeus nãoportugueses e, às vezes, orientais.

O meu ponto de partida será os indivíduos que contribuíram para as formulações e reformulações do mundo Atlântico Português e que fizeram com que ele funcionasse. Portugueses emigraram para todo o Atlântico. O período entre 1660 e 1760 viu uma mudança de perfil dos emigrantes cujas ocupações eram em grande parte ligadas à agricultura ou ao artesanato, para emigrantes caracterizados pela diversidade ocupacional, com habilidades de níveis mais altos, tais como mestres em seus ofícios, boticários, advogados e médicos. Homens de negócios experimentados tornaram-se comuns. Famílias metropolitanas enviavam parentes para portos no Atlântico norte e sul para adquirir experiência e construir redes de clientes. A emigração ainda era predominantemente de homens solteiros, mas (dependendo da origem, do destino, e da época) havia mais unidades familiares. Os principais fatores para a emigração variavam. Fatores que empurravam indivíduos incluíam epidemias, fome, guerra, indisponibilidade de terras adequadas para ganhar a vida, e leis de primogenitura. Fatores que atraíam abrangiam espírito de aventura, expectativas pouco realistas e a ignorância. Para alguns, ficar significava uma sentença de prisão, perseguição religiosa ou as galeras. Para outros com bens, uma profissão, habilidades ou talentos, as colônias representavam a oportunidade para uma posição financeira mais segura e status social. Somente o ato de atravessar o Atlântico já provocava um autoenobrecimento. 
SULCANDO OS MARES: UM HISTORIADOR DO IMPÉRIO PORTUGUÊS...

Viver no exterior sendo um português de nascimento poderia carregar uma marca inacessível para os pares em Portugal. A circunstância do nascimento melhorava a capacidade de um homem migrante de encontrar uma parceira no casamento ou o tornava elegível para um cargo público numa colônia, o que era negado aos nascidos no local. O lugar de nascimento, a ortodoxia religiosa e a "pureza de sangue" racial poderiam ser mais importantes no exterior do que em Portugal. No Brasil e na África portuguesa, uma hierarquia social era baseada numa complexa mistura de fatores, incluindo cor, percepções, e "qualidades" pessoais. A aquisição de prestígio e o reforço do status social eram incentivos poderosos para a migração.

As colônias Atlânticas variavam entre aquelas completamente indesejáveis até as altamente desejáveis. As Áfricas Central e Ocidental estavam na primeira categoria. A deportação para Angola podia ser equivalente a uma sentença de morte. Madeira e os Açores eram muito bem consideradas mas, pelos meados do século XVII, estavam superlotadas, e os primeiros migrantes estavam se mudando para o Brasil. O século XVIII viu o Brasil emergir na imaginação popular e na reputação geral como uma terra de oportunidades. Entre as décadas de 1690 e 1750, uma série de descobertas de ouro no Brasil estimulou ondas de emigrantes de Portugal e das ilhas Atlânticas. Junto com as enormes migrações internas, essas descobertas transformaram os padrões de assentamento no Brasil. Alguns migrantes gozaram de grande sucesso, alguns conseguiram somente o suficiente para viver, outros morreram na pobreza e ainda outros foram parte de uma migração reversa. Muitos emigraram esperando ficar no máximo alguns anos no exterior e depois retornar para Portugal para impressionar antigos vizinhos com suas riquezas. Alguns retornaram para Portugal, mas a maioria morreu longe da sua terra natal. Apatia, investimento emocional na família ou financeiro em terras ou no comércio, uma subsistência garantida, uma sensação de conquista, ou a recusa de admitir erros, levavam muitos a permanecer no exterior. Lá pelo final do século XVII e no século XVIII, as cidades e vilas no Brasil tinham planos e planejamento 
urbano reminiscentes daquelas de Portugal, com instituições religiosas e civis, e sistemas de governo que faziam com que os novatos se sentissem confortáveis. As vilas em Madeira e nos Açores tinham muita coisa em comum com as de Portugal. Luanda, no final do século XVIII, era uma cidade de estilo considerável. Pertencer a uma associação de artesãos, a uma Ordem Terceira ou irmandade em Portugal, também garantia privilégios e o direito de tornar-se membro ou facilitar o ingresso em instituições similares no ultramar.

Portugal não poderia ter criado esse mundo Atlântico sem a ajuda, forçada e voluntária, de não-europeus. Este foi menos o caso em Madeira e nos Açores, onde os nascidos na Europa ou descendentes de europeus eram a maioria, e onde solo, chuvas e topografia favoreciam a agricultura e a pecuária. Em Cabo Verde, Alta e Baixa Guiné, África Central e muitas regiões do Brasil, os nascidos em Portugal e brancos eram uma minoria absoluta. Para construir fortalezas, criar espaços comerciais ou assentamentos no continente africano, onde já havia Estados estabelecidos e sistemas comerciais, era melhor trabalhar através da diplomacia e com a cooperação e a indulgência de governantes locais. Aquelas invasões que os portugueses faziam em Angola eram invariavelmente atribuíveis a soldados nativos ou a intermediários. O clima e as doenças eram hostis aos europeus. Africanos forneciam mão-de-obra e habilidades em plantio, cultivo, colheita, corte de madeira, construção, transporte, satisfação sexual e auxílio militar. Os dois últimos estavam ligados na opinião real, já que era esperado que os filhos (em geral ilegítimos) se tornassem soldados e colonos. $\mathrm{Na}$ África, economias locais estavam em mãos africanas, como também estava a aquisição de mercadorias e o seu transporte para os portos, para exportar.

A situação no Brasil era muito diferente. Portugueses ignoraram a soberania dos ameríndios e se apropriaram das terras em nome do rei. Eles não conseguiam identificar facilmente os líderes indígenas ou reconhecer evidências de organização, religião ou hierarquia social nos autóctones. Os homens ameríndios eram coagidos ao trabalho forçado, apesar 
SULCANDO OS MARES: UM HISTORIADOR DO IMPÉRIO PORTUGUÊS...

das inconsistentes leis proibindo essa prática e as mulheres ameríndias eram tomadas como concubinas. Como um resultado da necessidade portuguesa de ajuda militar ameríndia contra os Holandeses e com os assentamentos no Amazonas, no Sudeste e no Oeste, os portugueses deixaram de descrever ameríndios em termos genéricos no século XVII e passaram a reconhecer a individualidade e a distinção dos povos indígenas. No século XVIII, governadores de Minas Gerais e Mato Grosso faziam propostas para os mais velhos e tentavam cooptá-los ou praticavam a política de dividir para dominar ${ }^{10}$. No Brasil, africanos e afro-brasileiros forneciam a principal fonte de trabalho físico ou coexistiam com trabalhadores ameríndios em algumas regiões, enquanto a mão-de-obra ameríndia era mais comum nas, sempre moventes, fronteiras. Mulheres africanas e de ascendência africana no Brasil tornavam-se amantes e concubinas de portugueses e luso-brasileiros, mas havia uma maior incidência de relações inter-raciais duradouras e até mesmo de casamentos "nas portas da igreja" do que na África. Uma população mulata tinha um papel proeminente no Brasil, como milicianos, soldados, comerciantes, fazendeiros, colonos e mineradores. Alguns deram grandes contribuições para a música e as artes barrocas ${ }^{11}$.

África e Brasil apresentavam desafios para os quais os portugueses careciam de vontade, conhecimento ou habilidades para confrontar. Africanos e ameríndios eram essenciais como batedores, guias em trilhas e rios, e para o conhecimento da flora e da fauna nativas. Portugueses dependiam dos ameríndios para compartilhar de seu conhecimento de como colher e usar plantas nativas como comida ou para seu potencial comercial. Alguns africanos e africanas tinham conhecimento de mineração e metalurgia indispensáveis para os mineradores portugueses no Brasil. A economia local e os mercados na África eram as áreas das mulheres, assim como no Brasil, onde o mercado local era dominado por escravas e libertas africanas e afro-brasileiras. $\mathrm{Na}$ África e no Brasil os não-europeus não eram somente visíveis nas economias locais, mas contribuíam para a economia do Atlântico. Os poucos comerciantes portugueses e luso- 
brasileiros em Luanda ou Benguela, no século XVIII, terceirizavam para africanos e luso-africanos a tarefa de viajar para o interior para reunir indivíduos, por troca ou coerção, e levá-los para os portos para o embarque nos navios em direção ao Brasil. Isso empoderava mestiços e intermediários africanos (pombeiros), que também tiravam sua parte nas transações. Isso levava a maiores custos para os agentes ou comerciantes em Benguela ou Luanda e para os intermediários no Brasil, que os repassavam aos compradores em forma de aumento ${ }^{12}$.

O Atlântico português incluía indivíduos e grupos que tiveram negada a participação completa na empresa colonial. Alguns eram vistos como indesejáveis e, dessa forma, descartáveis ${ }^{13}$. Ciganos foram perseguidos e ameaçados a cada oportunidade, mas formaram comunidades em Angola e no Brasil. Cristãos-novos se estabeleceram como homens de negócio, comerciantes, plantadores de cana-de-açúcar e mineradores ${ }^{14}$. Com frequência eles ou seus descendentes se casavam juntando-se a famílias de cristãos-velhos. Alguns tornaram-se padres católicos; consta que outros detinham cargos locais e na coroa, em Angola e, possivelmente no Brasil. Escravos africanos e seus filhos nascidos no Brasil tinham seus movimentos e atividades circunscritos, mas alforriados possuiam roças ou maiores porções de terra, tabernas e lojas, e podem ter ocupado cargos públicos. Indígenas nunca eram totalmente livres de maus-tratos ou assédio, mas muitos fizeram a vida como artesãos nos arredores de vilas ou vendendo sua produção, e indiretamente contribuíram para o comércio Atlântico.

Esses indivíduos formavam comunidades. Os ciganos, isolados pela língua, cultura, ocupação e pelo casamento, viviam em comunidades móveis e fixas em áreas costeiras e no sertão do Brasil e em Angola. Cristãos-novos, envolvidos principalmente no comércio e conhecidos como "A Nação Portuguesa", construíram pontes entre os Atlânticos português e espanhol, eram parte de diásporas alcançando a costa do Pacífico, e na América e na Ásia, e permaneceram ativos por todo o final do século XVII. Africanos, luso-africanos e afro- 
SULCANDO OS MARES: UM HISTORIADOR DO IMPÉRIO PORTUGUÊS...

brasileiros - não obstante os constrangimentos da escravidão compartilhavam heranças étnicas e culturais que sobreviveram à distribuição regional e, no Brasil, eram alimentados pelo influxo regular de novos escravos. Autoridades em Angola arbitrariamente exilavam reis "difíceis" e outros para colônias no Atlântico português e além. Eles eram apenas parte da diáspora africana, por todo o Atlântico caracterizada tanto individualmente quanto coletivamente como sendo transoceânica, transnacional (no sentido Europeu) e transcultural (no sentido Africano), e se envolveram em trocas recíprocas entre o Novo e o Velho Mundos. Alguns formaram assentamentos, dos quais Palmares no Nordeste do Brasil somente foi erradicado na década de 1690, depois de existir por quase um século. Indígenas formaram seus próprios enclaves, assim como os escravos muçulmanos em Salvador ${ }^{15}$.

Esses grupos compartilhavam pontos em comum: fluência em outras línguas além do português; interação com os portugueses, mas tendo comunidades separadas; fortes tradições culturais e identidades étnicas não-européias; sistemas religiosos existindo independentemente, em paralelo, ou sincreticamente, com o catolicismo. Todos reconheciam que, nas colônias portuguesas, o português era a língua "oficial", os modos de comportamento portugueses eram a norma e o catolicismo era a única religião aceitável. Falar em outras línguas que não o português, deixar de cumprir o critério português do que constituíam condutas e comportamentos aceitáveis, e expressões públicas de fé que não o catolicismo, poderiam resultar em sanções, prisão ou castigos físicos. O fato de tais comunidades terem sobrevivido testifica sua força. Elas resumiam multiculturalismo, intercâmbio, interação e a anômala situação de estar dentro e fora do mundo português. Senegâmbia, na verdade toda a costa da Alta Guiné, fornece exemplos da complexidade e variedade dos componentes que constituíam identidades no Atlântico. Homens portugueses (fugitivos da lei, de perseguição religiosa, ou de credores, aventureiros e lançados ou tangomãos), voluntariamente ou coagidos, desembarcaram na costa da Alta Guiné. Entre esses 
havia judeus e "Cristãos-Novos". Os últimos com frequência voltavam ao judaísmo. Eles se estabeleceram, casaram com mulheres africanas e tiveram crianças que se misturaram com os povos locais. As crianças mestiças chamavam a si próprias de "portuguesas". Diversas características contribuíam para essa auto-identificação: o comércio como sua principal ocupação; a língua portuguesa que falavam, embora mais tarde se transformasse num crioulo; a adesão ao catolicismo, mas misturado com crenças e práticas islâmicas, cristãs e africanas tradicionais; e culturas materiais, das quais as mais importantes eram as moradias num estilo arquitetônico característico. Marcadores identitários não eram fixos; estavam sempre mudando ou se reconfigurando em novas combinações. Inicialmente, tais colonos e seus descendentes estavam efetivamente além dos limites da influência portuguesa. Dependendo da localização, eles optavam por se colocarem sob a jurisdição portuguesa ao invés de estarem à mercê dos reis locais ${ }^{16}$. Colonos de Cabo Verde também eram mestiços e, por definição, parte do império português, embora falassem crioulo. Franceses e ingleses se estabeleceram mais tarde na Senegâmbia, trazendo ainda mais interacção social e cultural enquanto preservavam o movimento, a mudança e a fluidez que caracterizavam o início do Moderno Atlântico ${ }^{17}$.

Havia outros europeus neste "Mundo Atlântico português". O transporte era feito frequentemente em cascos de navios holandeses. Médicos franceses eram muito procurados por sua reputada habilidade no tratamento da sífilis. Havia colônias de ingleses, irlandeses, franceses, e espanhóis na Amazônia. O século XVIII, no Brasil, viu cônsules ingleses e residentes legais holandeses. Xenofobia e mêdo irracional levaram reis a negar a entrada de engenheiros de mineração e geólogos europeus nas áreas auríferas do Brasil até que fosse tarde demais. No Golfo da Guiné e na África Central, europeus continuaram a estabelecer postos de comércio no que os portugueses consideravam sua esfera de influência. $O$ fato de esses portos serem a base de um comércio cada vez mais intenso e com uma gama diversificada de mercadorias tornou o contrabando atrativo. Era realizado por 
SULCANDO OS MARES: UM HISTORIADOR DO IMPÉRIO PORTUGUÊS...

comerciantes portugueses baseados em Lisboa, por comerciantes portugueses no Brasil, por comerciantes brasileiros no Rio de Janeiro, em Salvador e seus associados em portos na África, por comerciantes holandeses, franceses, ingleses e espanhóis e por visitantes europeus reunindo informações comerciais sob o pretexto de serem viajantes.

A geografia das possessões portuguesas no Atlântico em 1660 permaneceu virtualmente inalterada um século depois, a não ser no Brasil como consequência de tratados bi-nacionais com Espanha. Marrocos perdeu sua antiga importância para Portugal. A Espanha controlou Ceuta e Tânger foi cedida (1661) para a Inglaterra. A cidade-fortaleza de Mazagão cresceu, em parte por causa de um influxo de condenados e indesejáveis de Portugal, e contou com uma guarnição, com comunidade comercial e religiosa, com artesãos e com famílias. A dependência das linhas marítimas vitais para munições e provisões, os ataques e cercos feitos por governantes locais e os assaltos no mar por corsários e pelos britânicos, tornaram a presença portuguesa insustentável. Em 1769, enfrentando o cerco de 120 mil mouros e berberes, Dom José I ordenou o abandono de Mazagão, que foi re-estabelecido na Amazônia como Vila Nova de Mazagão ${ }^{18}$.

No final do século XVII e no século XVIII, os arquipélagos eram os mais densamente povoados, mais comercialmente explorados, mais sistematicamente estudados e mais acessíveis de todos os lugares no Atlântico português ${ }^{19}$. Eles eram valorizados per se por sua importância comercial, econômica e agrícola, pelas vantagens estratégicas e militares comparativas que eles proviam para Portugal, pelo papel central na migração livre e nas diásporas africanas forçadas dentro do Atlântico, na oferta e procura de mão-de-obra e no comércio e circulação de informações. Longe de serem periféricos, eles eram parte vital do intercâmbio entre os hemisférios Norte e Sul, entre Europa, África e as Américas e portos de apoio de procura no Atlântico por navios da Carreira da Índia. Eles eram atores quintessenciais na história Atlântica e fazem com que se passe a 
questionar a aplicação genérica do modelo de centros e periferias para o Atlântico português.

Madeira e os Açores continuaram a ter papéis cruciais no comércio entre Europa, África e Brasil ${ }^{20}$. Ambos os grupos de ilhas permaneceram consolidadas socialmente, economicamente, politicamente e institucionalmente a despeito dos ataques holandeses, franceses, ingleses e mouros. Madeira era privilegiada pela localização, novos assentamentos foram criados na costa e no interior, e sua população cresceu pelo menos 60 por cento durante esse período. A ilha era famosa pela agricultura e alta qualidade dos vinhos, e prosperou apesar das atividades sísmicas nas décadas de 1740, 1750 e 1760. Apenas Funchal tinha o título de cidade. Os Açores compartilhavam algumas das mesmas características: atividade sísmica, especialmente em Horta e São Miguel, no século XVIII; crescimento populacional de cerca de 25 por cento; aumento da imigração de Portugal levando à superlotação; e novas vilas e pequenos municípios. As cidades portuárias de Ponta Delgada e Angra eram centros de poder, autoridade, riqueza, prestígio social e comércio. Havia mosteiros, casas magníficas e prédios municipais, especialmente em São Miguel e Ilha Terceira. Angra continha o principal forte do Atlântico português, embora tenha sido construído por espanhóis. As nove ilhas do arquipélago variavam em topografia, qualidade do solo e chuvas, e havia disparidades entre as ilhas em termos de população, colonização e prosperidade. A produção agrícola nos Açores para o mercado doméstico e para exportação incluía cereais, vegetais, frutas, tintura de ísatis, agropecuária e corte de madeira, além da pesca de peixes e baleias. Emigrantes de Madeira e dos Açores tiveram um importante papel na história social e econômica dos séculos XVII e XVIII no Brasil. Eles trouxeram técnicas agrícolas, uma forte ética do trabalho, e famílias já formadas. Importância social e vantagens financeiras facilitaram a entrada de alguns nos altos escalões da sociedade brasileira. Eles foram eleitos como juízes e vereadores de câmaras municipais, tornaram-se donos de fazendas e comerciantes, receberam mercês do rei e retratos daqueles madeirenses e açoreanos eleitos provedores 
SULCANDO OS MARES: UM HISTORIADOR DO IMPÉRIO PORTUGUÊS...

decoram o salão nobre da Santa Casa de Misericórdia da Bahia até hoje.

O panorama do Atlântico Português muda quando se vai para os arquipélagos do Cabo Verde e de São Tomé e Príncipe, e depois para o continente africano e para o Brasil. As 14 ilhas dos dois arquipélagos eram inabitadas antes da chegada dos portugueses, que posteriormente introduziram africanos para 0 trabalho. Nos séculos XVII e XVIII, a coroa ainda usava as ilhas como depósitos para criminosos e imprestáveis. Poucos portugueses e outros europeus mostraram interesse em colonizá-las por causa das doenças, do clima, das condições imprevisíveis para a agricultura, e de transtornos sociais e econômicos $^{21}$. Ambos os arquipélagos tinham populações predominantemente negras ou mulatas. As línguas africanas predominavam. O crioulo era mais amplamente falado do que o português. Populações africanas de nascimento e ascendência contavam com escravos e com pessoas livres. Apesar de compartilharem características culturais e demográficas, cada arquipélago tinha uma história diferente. Todas as ilhas de Cabo Verde tiveram atividades sísmicas, Fogo em particular, com pelo menos cinco grandes erupções vulcânicas entre os anos 1670 e 1760. Houve grandes secas e fome por todo o século, e epidemias frequentes. O clima, a degradação das terras e infestações de insetos e ratos tornaram a agricultura precária. Os cultivos incluíam vegetais, feijões, batatas, cana-de-açúcar, algodão e fumo para consumo doméstico ou exportação. A pesca e a caça às baleias dava rendimentos previsíveis, assim como davam o salitre, a madeira, os óleos e tinturas vegetais, especialmente litmus roccella. Os povoados em geral tomavam a forma de paróquias e vilarejos. Núcleos urbanos eram poucos. Ribeira Grande e Praia na ilha de Santiago competiam por predomínio. Havia uma forte presença religiosa. Capuchinhos e Franciscanos eram proeminentes na segunda metade do século XVII, e um seminário foi estabelecido. Em 1754 uma bula papal autorizou uma sede episcopal.

A coroa enfrentou muitos desafios: construir defesas contra ataques franceses e ingleses; controlar poderosas famílias; 
mediar conflitos entre clérigos e leigos; conter verdadeiras disputas públicas entre vereadores, homens do clero e governadores; e controlar o acúmulo, a fraude de preços, e a corrupção. O impacto do contrabando endêmico nas economias locais levou o rei a abrir portos importantes para o comércio internacional. A discórdia permanente, a violência física e o virtual colapso da agricultura, atingiram proporções catastróficas na década de $1760^{22}$.

São Tomé e Príncipe também teve uma história diversificada. Aqueles dias alcíoneos como um importante produtor de açúcar estavam num passado distante, mas as ilhas ainda colocavam o açúcar entre as exportações para a Europa, junto com tinturas vegetais, algodão, madeira e sal. Sabão era exportado para Angola, Brasil e Portugal. Plantas nativas da América, tais como milho e mandioca, eram cultivadas para uso doméstico. São Tomé contava com uma forte presença religiosa estabelecida por Capuchinhos italianos, Jesuítas e ordens religiosas que cooperavam com o clero secular. A cidade de São Tomé era famosa por um seminário e um clero secular negro e mulato que exerceu uma poderosa influência no arquipélago e também no continente onde constituia uma forte presença física nas imediações do Golfo da Guiné e em Angola. Os reis portugueses lutavam para proteger as ilhas de assaltantes europeus, especialmente franceses, mas tinham um sucesso limitado. São Tomé viveu muitas insurreições de escravos. Em São Tomé, não-europeus tinham suas próprias hierarquias sociais e alguns conquistaram importância e riqueza. Mulheres negras e mulatas, mestiços nascidos nas ilhas, tinham papéis importantes de liderança e constituíam uma elite social ${ }^{23}$.

Cabo Verde e São Tomé e Príncipe incorporavam muitos aspectos centrais para o campo da história Atlântica. Cada um era um foco para o comércio; ambos eram situados mais perto da África do que da Europa ou da América; cada um tinha populações, costumes e línguas predominantemente africanas. Apesar de minha descrição de seus problemas sociais, econômicos e administrativos, esses arquipélagos tinham um papel crucial em função de suas localizações e vínculos culturais 
SULCANDO OS MARES: UM HISTORIADOR DO IMPÉRIO PORTUGUÊS...

e comerciais com o continente africano. Meu foco aqui está em Cabo Verde, na África continental e no Atlântico ${ }^{24}$. Este arquipélago era um porto de parada para embarcações entre a Europa e a América, entre os hemisférios Norte e Sul, e para embarcações viajando além do Cabo da Boa Esperança. Na metade do século XVII, o arquipélago era o único importante grupo de ilhas colonizado no Atlântico Oriental ao sul do Trópico de Câncer, mas ao norte do equador e mais ou menos na mesma latitude das Pequenas Antilhas. A localização física e os sistemas de correntes e ventos garantiam fácil acesso a Portugal, aos Açores e a Madeira, à Alta Guiné, ao Golfo da Guiné, à África Central e ao Brasil. Salvador e Luanda eram mais ou menos equidistantes. Quaisquer que fossem suas deficiências na agricultura, em recursos naturais e demografia, a principal ilha do arquipélago, Santiago, e os portos de Ribeira Grande e Praia exemplificam a dimensão intercontinental e interhemisférica do comércio melhor do que qualquer outra ilha no Atlântico Português. Além dos produtos locais, importações da África, Europa ou América eram recolocadas em carregamentos para serem despachados para destinos que incluíam as Antilhas, América Espanhola e o Norte Europeu. O arquipélago era um lugar para testar a viabilidade do cultivo da flora européia e americana. Era um vibrante locus fora da costa para línguas africanas, costumes e sistemas de crenças de residentes africanos e mestiços. Africanos do continente próximo e de tão longe quanto a África Central lá convergiam para o envio para as Américas.

O arquipélago do Cabo Verde tinha uma longa relação com o continente. Essa relação foi consagrada através da criação da Capitania Portuguesa do Cabo Verde e Rios de Guiné ${ }^{25}$. No final do século XVII, a coroa autorizou companhias de comércio monopolista com nomes ligando o arquipélago às colônias portuguesas no Cacheu e Bissau na Alta Guiné. A região entre essas vilas era boa para a agricultura e a criação de gado. Os rios transportavam bens do interior para esses dois enclaves como: vegetais, óleos, peles, madeiras, marfim, algodão e tecido, exóticos tais como penas e cascos de tartaruga, e escravos. 
Esses portos e possessões portugueses na Alta Guiné ocuparam-se no comércio com o Norte e o Sul da Europa. Seus produtos, via Ribeira Grande e Praia, no Cabo Verde, encontraram mercados no Caribe, na América Hispânica, no Estado do Maranhão e Grão-Pará (Estado do Grão-Pará e Maranhão, entre 1751 e 1772) e no Estado do Brasil. Gerações de mercadores e capitães de navios entre as décadas de 1690 e 1760 criaram novos mercados para a produção local, reforçando a importância da Alta Guiné como responsável pela sobrevivência econômica de Cabo Verde, promoveram intercâmbios entre a costa e o interior naquela parte da África, e se aproveitaram completamente da proximidade da Alta Guiné com o Norte do Brasil, com a Europa e com o Caribe, e do fato de que havia menos competição de outros europeus do que em Angola. Estes dois portos constituíam uma âncora setentrional no continente africano para os interesses portugueses, e habilitaram Portugal a trazer uma nova dimensão para o comércio entre o Velho Mundo, o Norte do Brasil e o Atlântico Norte, assim como com o continente da Baixa Guiné e, especialmente, com Angola. Eles demonstram como o comércio Atlântico era mais complexo do que o modelo de um comércio triangular ou quadrilateral, e que qualquer porto ou região era um participante numa rede comercial múltipla, com ou sem um componente europeu, americano ou africano. Eles refutam a noção de que a participação africana no comércio Atlântico era fundamentalmente em conexão com o tráfico de escravos e dão a oportunidade para africanistas identificarem a diversidade, a intensidade e o amplo alcance de tal participação como uma parte essencial da história da África, bem como do Atlântico.

\section{Angola e Brasil}

As histórias de Angola e do Brasil tomaram cursos muito diferentes entre 1660 e $1760^{26}$. Na Angola Central, os portugueses moviam-se em direção ao leste e ao sul de Luanda. 
SULCANDO OS MARES: UM HISTORIADOR DO IMPÉRIO PORTUGUÊS...

Os indícios desse esforço eram poucos: guarnições em fortes, cuja influência era mais simbólica do que real e exerciam pouca influência além de sua vizinhança imediata; um forte construído em Caconda, no interior de Benguela em 1680, sendo transferido para o planalto em 1769; e feiras que eram espaços regionais de encontro. Uma ordem régia de 1758 concedeu liberdade para entrarem em áreas do interior até então restritas para qualquer um envolvido em comércio, com implicações para feiras e novas regiões para expedições escravizadoras. O governador sucumbiu às pressões feitas por comerciantes em Luanda e obedeceu mas não executou imediatamente ou completamente o intento real de promover o livre comércio ${ }^{27}$. Luso-africanos, condenados e gangues criminais inundaram os assentamentos instantâneos, criando problemas de lei e ordem. Tal confusão e violência demandou medidas governamentais para regular as novas feiras. Os portugueses aumentaram sua presença no vale do rio Kwanza. O rio tornou-se o veículo para as incursões portuguesas para o leste. Mas, em geral, esse foi um período de falsas esperanças e desilusões: a falha em abrir uma rota transafricana para a colônia portuguesa de Moçambique; falta dos recursos minerais altamente esperados, especialmente depósitos de ouro e prata; pouco progresso na agricultura e pecuária; uma carência de colonos portugueses; uma economia dominada pelas demandas por mão-de-obra nas colônias americanas; e capitães e comerciantes europeus competindo com os portugueses pelo comércio em portos no litoral ao norte de Luanda e no Congo, e em direção ao sul para Benguela e além. Dois assentamentos (Caconda e Quilengues) no interior de Benguela tiveram uma vida $\operatorname{curta}^{28}$. O governador em Luanda, o rei e seus conselheiros devem ter estado cientes dessa ameaça internacional para a economia doméstica de Angola, para o tráfico de escravos para o Brasil, e até mesmo para a integridade e sobrevivência de Angola como uma colônia portuguesa. Mas as ações corretivas da parte da coroa ou das autoridades portuguesas eram ausentes, atrasadas ou ineficazes.

Este século viu a emergência do Brasil no palco Atlântico como uma força importante: demograficamente, socialmente, 
economicamente e politicamente ${ }^{29}$. Havia uma extensiva migração interna se irradiando das áreas tradicionais de assentamento na costa com bolsões disseminados entre o Nordeste e São Vicente: da costa para o interior; dos centros tradicionais para o norte e o sul distantes; e, no século XVIII, da costa e do interior para o oeste. Movimentos migratórios internos de massa envolviam europeus, africanos, afrobrasileiros e até mesmo ameríndios. Acampamentos tornaram-se assentamentos, assentamentos tornaram-se vilarejos, vilarejos tornaram-se vilas. Poucas vilas tornaram-se cidades. Enquanto as cidades litorâneas mais antigas mantinham sua importância comercial, social e política, novos centros de população, de urbanização, de atividade econômica e de mercado tomaram forma. Terras tradicionais no interior foram retrabalhadas, novas ocupações no interior foram estabelecidas, outras foram dissolvidas, e ainda outras criaram novas redes comerciais sem um componente litorâneo. Enquanto Salvador e Rio de Janeiro gozavam de seu status central por causa de uma combinação de circunstâncias administrativas (seculares e religiosas) e comerciais, desenvolvimentos no Mato Grosso levaram a novas ocupações de terras nos Hinterlands de São Paulo, de Belém do Pará ou de São Luís do Maranhão, e mudaram as relações em resposta às novas configurações de oferta e procura ${ }^{30}$. A monocultura continuava (açúcar, algodão, etc), mas houve um aumento da diversificação agrícola e um obscurecimento das distinções entre criação de gado, agricultura, indústrias extrativistas e comércio. Categorias ocupacionais também se tornaram porosas: fazendeiros e lavradores de cana envolveramse com o comércio, tinham solares ou casas, participavam da vida urbana social e econômica; comerciantes compraram fazendas e plantações e eles ou seus filhos adotaram estilos de vida de fazendeiros e de senhores de engenho; negociantes constituíram o setor de serviços financeiros, mas investiram em terras e propriedades urbanas; mineradores tinham campos cultivados com alimentos e tabaco. Inventários de homens livres e ex-escravos revelam, por exemplo, a posse de um pequeno 
SULCANDO OS MARES: UM HISTORIADOR DO IMPÉRIO PORTUGUÊS...

sítio, de um cavalo, de gado e cabras, frequentemente, de uma loja ou até mesmo de uma taberna.

Este foi um século de crescimento da mobilidade social e econômica para alguns portugueses, luso-brasileiros, africanos, luso-africanos, afro-brasileiros e afro-luso-brasileiros no Atlântico Sul. Ele testemunhou um tráfico de escravos crescendo com grande velocidade e centenas de milhares de indivíduos no cativeiro. Uma percepção sensata é a de que a Igreja Católica e a escravidão eram duas instituições constantes durante todo o período colonial, e a influência de ambas permeou todos os setores da vida, da cultura, da sociedade, da economia e da política brasileiras. É contra este pano de fundo que dois grupos muito diferentes conquistaram grande importância no século XVIII. Um grupo foi o constituído por africanos e afro-brasileiros. Esse período testemunhou um crescimento no número de escravos que compraram, eles mesmos, sua liberdade ou que foram alforriados por um senhor. A incidência variava regionalmente, mas há indicações de que em Minas Gerais esta prática era mais frequente. Parece que era mais provável que aqueles nascidos no Brasil obtivessem sua liberdade do que seus equivalentes africanos. Eles não devem ser confundidos com aqueles afro-brasileiros nascidos livres. O resultado era um aumento no número de indivíduos, livres ou libertos, de origem africana, com consequências para a vida social e econômica na colônia ${ }^{31}$. O segundo grupo era uma classe sempre crescente de comerciantes portugueses e luso-brasileiros que de várias maneiras se envolviam no comércio regional, inter-regional, oceânico e transoceânico, tornavam-se ricos e muito influentes, e tinham capital para investir na infra-estrutura da colônia, assim como para gastos discricionários em artes, em igrejas e mansões, e no embelezamento de vilas e cidades ${ }^{32}$.

O século em discussão viu o contínuo intercâmbio entre Brasil e África. Havia intercâmbio de alimentos: batatas doces americanas eram levadas para a África, milho e mandioca tornaram-se artigos importantes nas dietas africanas, e plantas africanas foram trazidas para o Brasil. A Bahia tinha relações próximas com Benim e com a Costa da Mina e houve 
movimentos de indivíduos Portugueses e africanos entre os dois continents $^{33}$. Estes intercâmbios e vaivém de pessoas em ambas as direções foi de uma intensidade tal que superou aqueles intercâmbios entre a Cidade do Salvador e regiões do sertão bahiano. Sendo assim, é bem provável que os habitantes de Salvador tinham melhores conhecimentos e notícias mais atualizadas dos portos do Golfo de Benim do que da vila de Jacobina.

Tem sido amplamente afirmado, em relação ao final do século XVII e ao século XVIII, que o tráfico de escravos dominou os intercâmbios entre Brasil e Angola.

Há aspectos menos conhecidos que são inerentes a este tráfico. Alguns poucos produtos brasileiros encontraram um mercado em Angola. A cachaça/geribita brasileira substituiu bebidas locais africanas e vinhos e aguardentes portugueses na África Central. O tabaco bahiano tinha grande demanda na África Central para mastigação e fumo. Ambos tiveram consequências negativas, sociais e de saúde, para africanos ${ }^{34}$. O impacto da África sobre o Brasil durante esse momento se refletiu no mais intenso período, por quantidade, do trato de escravos. Doenças ou epidemias, que não eram nativas das Américas, mas que ocorriam no Brasil, eram atribuídas a origens africanas. Esse foi o caso de uma epidemia de febre amarela que arruinou cidades costeiras no Nordeste do Brasil nos anos 1680. Outras atribuições nasceram de percepções negativas de colonos no Brasil e de representantes da coroa, e eram espúrias. A preparação de comidas africanas se espalhou pelo Brasil. Embora os ingredientes pudessem ser virtualmente idênticos, o mesmo prato poderia diferir entre as duas colônias.

Dois aspectos tiveram um impacto permanente no Brasil. O primeiro foi a introdução no Brasil de línguas e costumes da África Central. O volume do tráfico de escravos, seus números absolutos para a primeira metade do século XVIII, e a rápida redistribuição de escravos após a chegada, levaram à disseminação imediata de línguas da África Central no Brasil. Isso foi acompanhado pela presença dos sistemas de crenças e práticas associadas com religiões tradicionais africanas. Tudo 
SULCANDO OS MARES: UM HISTORIADOR DO IMPÉRIO PORTUGUÊS...

isso impactou em variados graus as diferentes regiões da América portuguesa em termos de governo, segurança física, práticas comerciais, moralidade pública e vida doméstica. Aqueles rituais e cerimônias cristãs que eram feitos no Congo e em Angola também tiveram consequências para o cristianismo praticado por africanos no Brasil ${ }^{35}$. Tanto a África como o Brasil contou com carismáticas africanas e descendentes de africanos, tais como Dona Beatriz Kimpa Vita (1684-1706) no Congo e a mulher conhecida como Rosa Egipcíaca, considerada santa pelo povo de Minas Gerais ${ }^{36}$. A influência do Congo no Brasil foi profunda e duradoura, e mais conhecida pela coroação dos reis e rainhas do Congo ${ }^{37}$.

O tráfico de escravos angolano não era estático ou monolítico, mas suscetível à mudança. Capitães de navios ajustavam-se às condições na África que afetavam a oferta e procura, por exemplo, doença ou guerra, e mostravam perspicácia e imaginação para conseguirem um carregamento. Houve uma presença física de brasileiros no continente africano. $\mathrm{Na}$ segunda metade do século XVII, era comum famílias de mercadores portugueses terem um jovem parente num porto brasileiro, para ganhar experiência e fornecer uma âncora local. Também tornou-se uma prática padrão, para famílias de mercadores ou sociedades comerciais em Salvador e Rio de Janeiro, enviar parentes à África, não somente para checar o mercado africano e reportar o que vissem, mas também para ter um membro da família residente num porto africano. Nesse sentido, famílias cariocas e baianas estavam à frente. Uma inovação no contexto mais amplo do eixo Angola-Brasil ocorreu nos anos 1720. Mercadores baianos iniciaram um comércio entre Salvador e Benguela, ao invés de Luanda. Mercadores ou agentes baianos começaram a residir em Benguela, enquanto os cariocas favoreciam Luanda ${ }^{38}$. Uma contrapartida em relação à participação africana e afro-brasileira foi o comércio e transporte de metais preciosos no Atlântico. As Irmandades de Nossa Senhora do Rosário em Luanda e no Brasil enviavam carregamentos de ouro para Portugal, aparentemente como pagamento por uma estátua ou por trabalho artístico 
encomendado. Indivíduos africanos e afro-brasileiros - homens em sua maioria, mas mulheres de vez em quando, principalmente livres, mas às vezes escravos - também enviavam carregamentos de ouro em seus próprios nomes para Lisboa.

\section{Portugal e o Atlântico}

Os anos de 1660 a 1760 foram crucialmente importantes para Portugal e suas colônias Atlânticas. Este século viu a concentração da atenção real e dos interesses nacionais no Atlântico. Indivíduos portugueses participaram no assentamento, na colonização e na comercialização no Atlântico em números muito superiores àqueles registrados na entidade administrativa portuguesa conhecida como o Estado da Índia, que se estendia de Moçambique ao leste. Houve migração incessante em todo o Atlântico Português por mar, rio e terra, uma corrente de seres humanos entre o Velho Mundo (Europa, África) e o Novo, entre ilhas e continentes e, dentro de continentes, novas configurações migratórias. O panorama do Atlântico português mudou aceleradamente. Um léxico foi criado para descrever indivíduos bi- e multirraciais. Indivíduos e grupos se autoidentificavam de novas maneiras e uma cultura crioula pan-Atlântica tomou forma.

Por todo esse Atlântico, novos mercados foram criados; redes de comércio foram desenvolvidas, expandidas e contratadas ou foram reformuladas em novas combinações; áreas do interior ganharam uma reputação, estimularam novos mercados ou fontes de matérias-primas e aumentaram ou diminuíram. Este foi um século caracterizado pelo ir e vir, pelo constante movimento, pela mudança e pelos retrocessos, assim como pelos avanços. Houve evidentes disparidades entre localidades e regiões, exemplificadas pelas histórias muito diferentes do Brasil e de Angola, e pela mudança de destino de 
SULCANDO OS MARES: UM HISTORIADOR DO IMPÉRIO PORTUGUÊS...

regiões como o Nordeste e o Sudeste brasileiros na primeira metade do século XVIII.

Parte da nossa história relaciona-se à forma como, durante este século, colonos exerceram mais agência sobre seus próprios destinos, fugiram de obrigações tradicionais para com a coroa, tomaram iniciativas coletivas e individuais independentes da coroa ou de seus representantes e se envolveram em intercâmbios que eram intercoloniais e sem um componente metropolitano. A consolidação de comunidades comerciais por todo o Atlântico Português, a gama pan-Atlântica de suas atividades e seu acesso ao capital levaram à criação de novas redes, decisões e práticas unilateralmente independentes da coroa, da intervenção oficial, ou de financiamento metropolitano. Isso permitia uma maior adaptabilidade às condições de mudança de mercado. O lado negativo era que isso poderia levar a práticas comerciais não-autorizadas ou clandestinas, ao intercâmbio de mercadorias que eram proibidas ou que não respeitavam um critério de qualidade, ao uso de rotas nãoautorizadas por terra ou por mar, e a falha em respeitar as regulações específicas dos portos. $\mathrm{Na}$ pior das hipóteses, práticas comerciais tornaram-se parte do que eu caracterizo como uma "cultura de evasão endêmica", que incluía contrabando, intercâmbios ilegais com não-portugueses, cunhagem de moedas falsas, raspagem de moedas, mistura de estanho raspado com ouro em pó, tritura de folhas de tabaco com areia e não pagamento de taxas e impostos de licença.

A deferência foi substituída por maior independência de pensamento e ação, a obediência cega foi trocada por acordos negociados, colonos ou seus representantes escolhidos tinham voz em Lisboa e foram ouvidos pelo rei. Uma parte importante de minha narrativa é que precisamente durante o reinado de Dom João V, quando Portugal esteve mais perto de uma era de absolutismo, as aspirações coloniais eram proclamadas com voz mais alta, pontos de vista coloniais eram mais ouvidos na corte, colonos tinham um maior poder de decisão no estabelecimento das prioridades coloniais e não se prostravam aos interesses metropolitanos. Houve um tom contraiante difundido pelo 
Atlântico Português ainda que mais em evidência na África e na América Portuguesas. Mas isso não cresceu ao ponto de uma revolução. Os levantes no século XVIII no Brasil eram limitados e foram expressões de desagrado popular provocado por circunstâncias de ordem social ou econômica, enquanto houve outros levantes frutos de uma mistura de circunstâncias locais e influências ideológicas oriundas de países à orla do Atlântico norte e que chegaram ao Brasil por via oceânica.

Uma perspectiva muito diferente sobre a efervescência na colônia, até recentemente ignorada por uma historiografia que viu o Brasil mais a partir de um olhar costeiro do que do interior ou do oeste distante, foi fornecida por eventos no Sertão Oriental, onde migrantes na fronteira, procurando se estabelecer nas florestas no leste de Minas Gerais, confrontaram-se com os indígenas, iniciando com isso oito décadas de resistência indígena. O que definia "fronteira" naquela região permaneceu elusivo para as pessoas da época, assim como foi o caso alhures no Brasil e em Angola, onde "fronteiras ocas" eram a norma.

Alguns produtos de colônias no Atlântico português desfrutaram de nichos de mercados, mas outros estavam em competição direta nos mercados europeus com produtos idênticos, especialmente das Índias Ocidentais, e por instalações portuárias melhoradas no Norte e no Sul da Europa. O povo português se beneficiou pouco da chegada em portos portugueses de carregamentos do Brasil e de outros lugares, que faziam transbordo para o Norte da Europa, Espanha e Itália. O símbolo das relações colônia-metrópole, a famosa "vaca leiteira" na frase de Dom João V, não deu os lucros esperados. Essa situação foi exacerbada por exceções e privilégios exigidos, por tratado e diplomacia, pelas nações estrangeiras. Os Tratados de Methuen $(1702,1703)$ foram muito prejudiciais, politicamente e economicamente tanto para Portugal quanto para as suas colônias no Atlântico. Investimentos inadequados em infraestrutura dentro de Portugal e a extravagância real forçaram Portugal a comprar coisas elementares tais como cereais, alimentos e produtos manufaturados da Inglaterra e de outras nações européias. Portugal sofreu um problema na balança de 
SULCANDO OS MARES: UM HISTORIADOR DO IMPÉRIO PORTUGUÊS...

pagamentos. Tal foi a força do ressurgimento agrícola no Brasil, das descobertas de ouro, entre as décadas de 1690 e 1740, e de diamantes, nos anos 1720, que Portugal foi salvo do desastre, mas a um custo muito alto. O declínio da produção de ouro no Brasil, registrado logo nos anos 1730, e uma vertiginosa redução depois de 1750, foram devastadores para Portugal.

Contrastando com essa grave realidade, estava a imagem de Portugal associada com o personagem de Dom João V, que era motivo de inveja para seus contemporâneos, que construiu a estatura de sua nação na Europa, que foi um Mecenas para um exército internacional de artistas, artesãos, arquitetos e construtores, que foi estimado pelo Papa, construiu igrejas, palácios e prédios, e que criou extravagâncias, fossem elas cerimônias de casamento ou embaixadas diplomáticas ${ }^{39}$. No século sob discussão, o Brasil superou as Américas Espanhola e Britânica em números de chegada de pessoas do Velho Mundo (Europa e África) e, possivelmente, no volume de comércio para a Europa, se as Índias Ocidentais forem excluídas. A ironia era que, no ápice da era do absolutismo, personificada por Dom João $\mathrm{V}$, pessoas do mundo Atlântico português já tivessem aprendido que eles poderiam sobreviver independentemente de uma presença metropolitana portuguesa. Houve de facto reversão de papéis. O centro de gravidade mudou do Atlântico Norte para o Atlântico Sul, da metrópole para as colônias ${ }^{40}$. O reconhecimento dessa reversão de papéis estava implícita na observação, na década de 1730, feita por um presciente cortesão, de que a sobrevivência de Portugal dependia das riquezas brasileiras. Em seu conselho para Sua Majestade Real, sugeriu que ele [Dom João V] estaria mais confortável e seguro em uma terra de riquezas (Brasil) do que em um país que oferecia somente privação (Portugal).

O ano de 1750 viu a chegada ao trono de Dom José I e, criticamente para o Atlântico Português, o governo autocrático de seu Primeiro Ministro, que entrou para a história como o Marquês de Pombal, e que se dedicou a reverter o que ele viu como um declínio progressivo no destino de Portugal ${ }^{41}$. O Atlântico era central para a mentalidade estratégica e 
mercantilista de Pombal. A transferência (1763) da capital do Brasil de Salvador para o Rio de Janeiro reconhecia a importância e o intenso envolvimento no comércio Atlântico e transoceânico do segundo. Pombal criou mesas de inspeção em importantes portos do Brasil para monitorar a qualidade das exportações (particularmente, açúcar e tabaco), nomeou superintendentes para questões marítimas e supervisão dos depósitos reais. Ele criou duas companhias comerciais monopolistas baseadas em Lisboa para estimular as exportações agrícolas brasileiras e guarantir uma oferta regular de mão-deobra africana. A primeira se concentrou no Grão-Pará e no Maranhão; a segunda em Pernambuco, cujos dias tranquilos abastecidos de açúcar estavam num passado distante. Alguns dos investidores residiam em Pernambuco, Bahia e Angola, mas a maioria em Portugal. Estas companhias promoveram o controle da coroa, integraram o Norte do Brasil no comércio Atlântico, contiveram competidores europeus, como foi o caso das pretensões francesas na Alta Guiné, reforçaram uma presença portuguesa no Cacheu e em Bissau, e fortaleceram laços entre os arquipélagos de Cabo Verde e São Tomé e Príncipe no leste do Atlântico. Pombal encorajou mercadores brasileiros a procurarem por escravos em Moçambique, trazendo um novo participante para o trato de escravos, e abriu o caminho para o comércio direto Brasil-Índia, que, cheio de implementações legais, demorou até depois da década de 1790.

Três medidas Pombalinas ressoaram por todo o Atlântico Português. Em consonância com sua defesa do mercantilismo, ele removeu nobres de posições de poder e autoridade e os substituiu por plebeus com comprovada astúcia financeira e sucesso comercial. Uma ordem diferente de reformas impactou a educação e a formação da elite. Homens jovens viajaram da América Portuguesa, da África Portuguesa e dos arquipélagos Atlânticos para Portugal para terem educação superior. A reforma de Pombal e a secularização da Universidade de Coimbra encorajaram essa prática. Ao invés de ficar em Portugal, entrar para os serviços da coroa ou para ordens sagradas, cada vez mais brasileiros diplomados retornavam para 
SULCANDO OS MARES: UM HISTORIADOR DO IMPÉRIO PORTUGUÊS...

o Brasil, e tornavam-se parte de uma elite crioula. Pombal também declarou ser ilegal a centenária distinção entre cristãosvelhos e novos, erradicando oficialmente o estigma ligado aos segundos. Comerciantes, homens de letras e profissionais contribuíram para os movimentos em direção à independência do Brasil.

\section{Historiografias: em busca de um equilíbrio}

Nesta minha tentativa neste "novo" ramo da historiografia, tenho-me esforçado a seguir as normas, ao meu entender, da "Atlantic History". Uma característica desta historiografia é que predominam as perspectivas desde o ultramar e não da metrópole, e os interesses coloniais e não os de Portugal. Os crioulos e não os reinóis, e as populações bi- ou multirraciais, e não aqueles indivíduos brancos, tornam-se os pontos de referência humanos. As culturas, línguas, comportamentos, crenças, organização doméstica, hierarquias sociais, modos de governo, redes comerciais de Africanos em África, AfroAmericanos no Brasil e os povos autóctones das Américas existem numa base de igualdade com os dos europeus. Assim, a noção de um Atlântico crioulo ou um Atlântico Africano merece a nossa atenção, como também é o caso de um Atlântico inglês, francês, português, espanhol ou holandês.

Ao meu ver, as duas perspectivas - aquele que se pode caracterizar de imperial ou nacional e aquele que tem os atributos encapsulados na noção e na prática de "Atlantic history" não representam dois polos naquele leque de aproximações representadas por uma historiografia que está sempre em evolução. Assim, eu considero estas duas aproximações ou perspectivas como instrumentos de análise e de interpretação que não são opostos um ao outro mas complementares. 
O problema não reside na perspectiva, nem na aproximação, nem na metodologia, mas no fato de que nós, sendo historiadores, estamos habituados a organizar os nossos materiais e mesmo os nossos modos de pesquisar ou analisar dentro de um quadro/armação. No pior dos casos, o quadro imperial pode estimular um exercício de reductio ad absurdum, provocado pela ênfase nos componentes e entidades da construção administrativa imperial e do poder no centro: o Desembargo do Paço, a Mesa da Consciência e Ordens, a Casa da Suplicação, o Conselho da Fazenda, o Erário Régio, o Conselho de Estado, o Conselho de Guerra, as secretarias de Estado e o Conselho Ultramarino. Estas entidades constituem não apenas a administração ao centro de Portugal e de seu império, mas a administração criada pela coroa, o verdadeiro centro de poder e autoridade. Evidentemente tal enquadramento restringe $o$ horizonte das nossas perguntas, das nossas pesquisas, da maneira com que propomos hipóteses de trabalho, e o processo subsequente de formular, reformular e modificar até chegar a uma tese viável e raciocinada. De fato, o ponto de conflito das duas aproximações à disciplina de história reside menos no encontro de uma aproximação imperial e aquela de "Atlantic history", e mais no fato de serem as prioridades e modus operandi dos partidários de "Atlantic history" antitéticas à ideologia, às mentalidades, e às práticas que caracterizavam o Ancien Régime: a concepção corporativa da sociedade, o regime senhorial e uma sociedade de ordens, a cultura jurídica, as redes clientelares, serviços e mercês ${ }^{42}$.

A noção de "Atlantic History" torna-se atraente porque é bastante ampla, escapa de ser definida em termos com que os historiadores são habituados: o império; a nação; e os aspectos políticos, administrativos, econômicos, sociais e culturais. Oferece a cada historiador(a) a possibilidade de adotar aquela perspetiva ou dimensão que mais ressoa com ele ou ela, integrála na sua própria interpretação da história ou adotá-la para complementar e, preferivelmente, transcender os parâmetros aos quais esteja acostumado/a. A "Atlantic history" é eminentemente suscetível a ser manobrada para satisfazer as 
SULCANDO OS MARES: UM HISTORIADOR DO IMPÉRIO PORTUGUÊS...

idiossincracias individuais. Para aqueles especialistas na história européia, tem o potencial de oferecê-los a oportunidade de adotar uma nova aproximação, isto é, para considerer as repercussões e as influências não apenas das colônias dos poderes europeus mas também daquelas regiões, entidades políticas, sociedades, e culturas que ficaram isentas da ocupação por europeus, quer dizer "O Atlântico na formação de Europa". Outros historiadores especialistas na chamada "História da expansão europeia" (uma interpretação já fora de moda por causa de seu marcado eurocentrismo) possam revigorar ou ampliar as suas aproximações pela incorporação dos conceitos e interpretações tiradas de "Atlantic History". Outros historiadores dedicados ao estudo dos impérios, de nações, ou de estados europeus podem ser incentivados a incorporar uma dimensão comparativa, sem sair do molde de história imperial.

Algo fundamental à "Atlantic History" é a exigência de aceitação de um novo paradigma e, da parte dos historiadores, de uma reorientação que dá aos oceanos uma importância igual àquela prestada aos continentes, e que tenham consciência de pontos de referência marítimos: sistemas de ventos e de correntes; sazonalidade marítima baseada em forças naturais que impõem a sua própria cronologia nas estações ou temporadas mais convenientes para viagens marítimas; profundidade das águas; baixios e bancos de areia; rochas submersas e penhascos; distâncias e tempo de viagem entre portos baseados em condições marítimas; a existência de ilhas como pontos de abastecimento e de água fresca; e de baías e estuários que oferecem ancoradouros seguros. Existe também uma outra ordem social, distinta daquela que prevalece em terra, entre homens do mar com as suas prioridades, modos de comportamento, organização social e hierarquias, vocabulário e mesmo superstições.

Queria, em conclusão, colocar o aparecimento de "Atlantic History" na consciência de alguns historiadores até ao ponto de se tornar quase moda, no contexto da historiografia portuguesa e brasileira, tratar dos fatores que fazem com que esta 
historiografia luso-brasileira seja distinta, e discutir as lições e as oportunidades que uma perspectiva de "Atlantic history" ofereça para os historiadores de Portugal e do Brasil. Tenho que insistir em que o Atlântico e a consciência do Atlântico fazem parte inalienável da historiografia e literatura de Portugal desde o século quinze e do Brasil desde o século dezesseis ${ }^{43}$. Não poderia ter sido de outro modo. Os portugueses familiarizavamse com os sistemas de ventos e correntes e adotaram uma atitude perante o Atlântico em que o oceano foi considerado uma oportunidade e não um obstáculo. Portugal foi a única nação européia a ter colônias no Atlântico norte e sul antes de 1492, e a primeira nação européia desde o século 16 a exercer soberania em ambas as orlas do Atlântico subequatorial. Também foi a única nação européia a ter representantes da coroa no posto de governador na África e na América portuguesas antes de 1600. Estas circunstâncias cronológicas atribuem a Portugal uma distinção sem par entre as nações européias. Igualmente, eliminam qualquer elemento de surpresa, de novidade ou de revelação a respeito do Atlântico.

A geografia favoreceu a presença portuguesa no Atlântico e contribuiu decisivamente para facilitar não apenas a colonização inicial mas também um nível de interconectividade sem par entre os hemisférios norte, sul, oeste e este. Os arquipélagos de Madeira e Porto Santo e dos Açores inicialmente e, depois, de Cabo Verde e de São Tomé e Príncipe, atingiram uma importância inicial estratégica comercial, militar, e com núcleos de colonização, subsequentemente como pontos de articulação entre Europa, África e América, e entre o Atlântico, o Mar Árabe e o Oceano Índico.

A geografia beneficiou o Atlântico português pela multiplicidade de baías e estuários que ofereciam ancoradouros não apenas seguros mas também com adequada profundidade de água. O Brasil contou meia dúzia de baías com condições naturais adequadas para navios e frotas capazes de serem envolvidos no comércio oceânico e transoceânico. Rios navegáveis em África e no Brasil facilitaram a penetração para o interior dos respectivos continentes, e permitiram o trasbordo de 
SULCANDO OS MARES: UM HISTORIADOR DO IMPÉRIO PORTUGUÊS...

cargas dos navios do percurso oceânico para a cabotagem. De fato, esses portos na costa brasileira exerceram as funções de portos de chegada e destino. Atingiram a função de pontos de articulação entre o oceano e o continente. Ademais, estes portos foram núcleos cujos Vorlands (para usar uma palavra tirada do vocabulário de geógrafos) podiam ser Luanda ou portos do Golfo de Benim enquanto concorrentemente serviram como núcleos de referência para Hinterlands que podiam incluir regiões nos interiores do Centro, do oeste, do norte e do sertão. Os portos maiores de Angola e do Brasil ficaram dentro de 5 graus de latitude uns dos outros. Nenhuma outra colônia européia no Atlântico podia competir com Luanda e Rio de Janeiro cuja posição geográfica $\left(8.50^{\circ} \mathrm{S} 13.15^{\circ} \mathrm{E}\right.$ e $22.45^{\circ} \mathrm{S}$ e $43.15^{\circ} \mathrm{W}$ respectivamente) e hidrográfica privilegiou a sua participação como pontos de escala no comércio entre o Atlântico e para além do Cabo de Boa Esperança.

Existe a tentação de sugerir que apenas essas circunstâncias possam ter contribuído para um excepcionalismo Luso-Afro-Brasileiro no contexto do Atlântico. É bom insistir em que os povos autóctones do litoral Africano do Atlantico e os Ameríndios do litoral Americano do Atlântico não se aproveitaram do oceano a não ser para subsistência alimentar. Foram os portugueses, tanto como os espanhóis, franceses e ingleses, que se aproveitaram ao máximo do potencial do Atlântico e construíram um Atlântico baseado em prioridades européias $^{44}$. O que distingue as atividades dos Portugueses é que na segunda metade do século dezesseis estavam lançando iniciativas concorrentes em ambas as orlas do Atlântico sul: na África Central e no Brasil, com trajetórias totalmente distintas, e com resultados bem diferentes. A iniciativa na África central foi circunscrita pelo fato de existirem estados, reinos e mesmo impérios, com hierarquias estabelecidas e redes comercias enquanto no Brasil os Portugueses ignoraram a possibilidade de soberania indígena. Os Africanos mantinham a autonomia dos seus reinos e suas terras por resistência armada enquanto no Brasil os Ameríndios, depois de hostilidades, conservaram a sua autonomia pelo expediente de se retirar, in seriatum, de contato 
com os Portugueses. O que distingue o caso brasileiro é que o processo de encontros foi em processo rolante através de três séculos e ainda no século dezoito houve uma época de crise no sertão este de Minas Gerais que levou a oito décadas de hostilidades. Os portugueses experimentaram e enfrentaram as mesmas dificuldades que os seus contemporâneos europeus, mas o fato de serem em dois continentes concorrentemente criou uma situacão sui generis. Sendo um "império tripolar" (Portugal, Angola e Brasil), a usar a caracterização de José Jobson de Andrade Arruda em referência à esfera de influência de Portugal no Atlântico, coloca a sua análise discernente dentro do quadro imperial, enquanto o que me interessa é colocar em discussão precisamente aqueles aspectos que mereçam a nossa atenção por se manifestarem apesar daquele quadro de um "Império luso-afro-brasileiro nascido do mar", expressão de Charles Boxer ${ }^{45}$.

Alguns dos mais ilustres historiadores brasileiros contemporâneos já evidenciaram uma predisposição para uma perspectiva que se aproxima àquela dos praticantes de "Atlantic History". O diabo e a Terra de Santa Cruz; feitiçaria e religiosidade popular no Brasil colonial (São Paulo: Companhia das Letras, 1986), da autoria de Laura de Mello e Sousa, foi um livro pioneiro na procura e uso das fontes, um modelo pela conceitualização a um nível sofisticado, e pela sua orientação multidisciplinar e multicultural (européia, indígena e africana). Este estudo atravessou as fronteiras temporais e espaciais, desemaranha os fios da madeixa do imaginário popular européia e dos preconceitos, revelou a polarização a respeito do Brasil sendo visto entre Deus e o Diabo, estudou a feitiçaria e as práticas mágicas na vida cotidiana da colônia e revelou a diversidade dos aderentes, a multiplicidade das suas crenças, e, quanto à religiosidade popular, empregou várias camadas da população brasileira da época. Luiz Felipe de Alencastro manifestou (inconscientemente ou não) a sua assimilação das perspectivas da "Atlantic History". O seu Trato dos Viventes trata dos vínculos entre Angola e Brasil e uma certa reciprocidade em que circunstâncias e mesmo atos de 
SULCANDO OS MARES: UM HISTORIADOR DO IMPÉRIO PORTUGUÊS...

indivíduos em uma colônia ressoaram na outra, sempre de uma perspectiva tropical e do hemisfério sul. No prefácio escreveu o seguinte:

A propósito do modo de escrever, é preciso notar que o território do historiador da Colônia deve abranger toda a extensão da lusofonia, da documentação ultramarina onde estão registrados os contatos entre as culturas que nos formaram. Além do mais, numa cultura tradicionalmente oral como a nossa, um meio privilegiado de patentear a presença do passado consiste em dar relevo à perenidade das palavras. ${ }^{46}$

Por serem habitantes de um país que, através de sua história, se tornou sinônimo com a convergência de culturas, de etnicidades, de crenças e práticas religiosas, e por fazer parte dos movimentos migratórios oceânicos e terrestres de indivíduos, do intercâmbio de pessoas, de produtos, de flora e fauna, e de mentalidades e idéias, os historiadores brasileiros estão numa posição privilegiada para se aproveitarem de "Atlantic History". Já existem no Brasil núcleos de historiadores, sobretudo nas universidades no Sudeste do Brasil que têm incorporado nas pesquisas as metodologias e tratamentos de temas que fazem parte do corpus historiográfico dos "Atlanticistas". Outros estão lançando pesquisas que têm enorme potencial para serem consideradas como parte desta nova historiografia, mas ainda não conseguiram afastar-se de uma perspectiva associada com o Antigo Regime e a dinâmica imperial portuguesa.

O praticar "Atlantic History" tem duas dimensões. Uma reflete uma disposição de ânimo, coragem, e mesmo audácia de se aventurar metodologicamente e conceitualmente em terras ou mares onde por enquanto não há caminhos marcados nem enquadramentos tradicionais. Tal historiador considera o ímpeto e movimento majestoso, mesmo inexorável, da história sem contextualizar o inquérito dentro de parâmetros conceituais tradicionais, e ainda menos dentro de fronteiras impostas por circunstâncias geográficas e cronológicas, e outras barreiras 
como produtos da ambição humana. Esta disposição tem o potencial de abrir novas avenidas para inquéritos históricos. Por exemplo, o conceito de "descentralização" incentiva historiadores a estudar indivíduos ou grupos que desafiam submeter-se a serem classificados apenas por uma característica, por terem múltiplas identidades. Um exemplo seria o daqueles judeus, católicos, cristãos-novos e marranos, conhecidos genericamente pelos contemporâneos como "la Nación portuguesa" ou simplesmente como "La nación" ou "a nação". Foram ligados pelas suas atividades comerciais mais do que pelas suas características de hibridez cultural e religiosa, e suas redes comerciais incluíram Salvador e Recife, Buenos Aires, e Luanda no Atlântico sul ${ }^{47}$. O Brasil colônia contava com vários indivíduos que exemplificaram tal hibridez: os bandeirantes; personagens carismáticas tais como o autoidentificado "Príncipe do Brasil" andando pelo sertão baiano e pernambucano, e os cunhamenas. Houve também aqueles indivíduos que ficaram nas periferias mas os quais, precisamente pelos seus atributos multiculturais, tornaram-se indispensáveis como intérpretes não apenas linguísticos mas culturais Os líderes das santidades, índios ou mamelucos, instruíram os seus adeptos com histórias tiradas da Bíblia misturadas com mitos indígenas. Tiveram apelidos associados com mitos tupis, sendo assim considerados como possuidores de poderes sobrenaturais e mesmo divinos ${ }^{48}$. Existem indivíduos de nascimento ou ascendência Africana que também manifestaram características bi-culturais e aptidões plurilinguísticas. Uma variante, ainda pouco estudada, foram aquelas personagens especificamente designadas por um rei ou um chefe para representar os seus interesses e, se fosse necessário, serem mediadoras. Durante o período colonial, vários reis africanos mandaram embaixadores para os holandeses e para o governador-geral ou vice-rei em Salvador, para tratar de interesses recíprocos comerciais, e mesmo para arranjar uma cônjuge! Outros exemplos da descentralização da história seriam na linguística histórica: a multiplicidade de línguas faladas pelos escravos e as diversas línguas crioulas faladas nas orlas do Atlântico. 
SULCANDO OS MARES: UM HISTORIADOR DO IMPÉRIO PORTUGUÊS...

A história brasileira e aquela do Atlântico sul são repletas de temas altamente suscetíveis a um tratamento de acordo com as prioridades e aproximações de "Atlantic History". Estavam presentes no Brasil colonial aderentes do Catolicismo, Judaísmo, Islã, Protestantismo, religiões africanas, religiões afrobrasileiras, religiões ameríndias, e devocões que aparecem, desaparecem, reformulam-se, e se inventam em novas configurações. As religiões e a religiosidade oferecem uma gama de oportunidades para o historiador. O que impresiona são os aspectos que compartilham: enraizamento físico e difusão pelo Atlântico e dentro do Brasil; grau de conservação da autenticidade original; líderes espirituais; instrumentos de instrução; instrutores, intérpretes, ou catequistas; modos e instrumentos de conversão ou coerção; ritos de iniciação; cerimônias; o papel da música instrumental, da canção e da dança. No caso do Catolicismo, merecem a nossa atenção as devoções dedicadas à Virgem e aos santos, os atributos raciais, sociais e econômicos dos aderentes; identificar, individualmente ou coletivamente, aqueles que tomaram a iniciativa e guiaram tais congregações; as relações entre as irmandades e com a igreja secular; os guias de conversão, sermões, catequismos e as traduções das orações e da Bíblia.

$\mathrm{O}$ conceito e a realidade do que constituiu o que conhecemos pela palavra "família" suscita perguntas. Foi caracterizada pela homogeneidade ou pela heterogeneidade? Quais foram as distinções entre "famílias" atribuíveis a fatores culturais, às forças extrafamiliares, às pressões da parte de um líder espiritual ou um chefe ou dos outros habitantes de uma comunidade? Quais foram as expectativas de um homem ou de uma mulher, um da outra, e qual foi o incentivo para juntaremse? Será que a convivência era uma característica fundamental? O historiador tem que ter cautela em usar a palavra "familia", visto que esta designação possa ser totalmente errônea e inadequada, e que qualquer palavra descritiva depende do contexto cultural, de fatores sociais prevalecentes, da região e mesmo da época. Mesmo sendo assim, o estudo da "família" no 
Atlântico luso-afro-brasileiro torna-se básico à nossa compreensão das sociedades.

Um dos atributos dos aderentes à "Atlantic History" reside na sua receptividade ao prospecto de sair do seu campo acostumado de história e saltar o muro e entrar nos jardins cultivados por aderentes de outras disciplinas acadêmicas. Algumas serão aparentadas ou cognatas; outras bem afastadas da história. A linguística histórica é tal jardim raramente visitado por historiadores, mas que possui um enorme potencial por tratar-se de línguas como expressões de uma cultura ou culturas. O Atlântico Luso-Afro-Brasileiro conta com várias formas de línguas crioulas raramente submetidas à análise por historiadores ou por falta de instrução ou por serem atemorizados pelos linguistas profissionais. É pena porque o estudo de línguas e do vocabulário é capaz de fornecer ao historiador informações sobre a vida colonial e sugerir novos campos de pesquisa. A música compartilha pontos em comum com as línguas não apenas como meio de comunicação, mas porque tanto a música quanto os instrumentos são ainda mais suscetíveis do que as línguas à migração, a serem produtos de uma cultura ou de origens policulturais, de se adaptarem a novas condições e transcender fronteiras físicas, espaciais e mesmo temporais, e interagir com uma variedade de influências exteriores. O Brasil oferece um raro e rico campo, abrindo caminhos para pesquisas sobre a passagem de instrumentos e de musica religiosa e popular da Europa e da África para o Brasil, da interação das duas tradições, e da reação da parte delas à música autóctone, e vice versa ${ }^{49}$. Outras disciplinas cognatas são a história da arte, das ciências e tecnologia, a história de medicina e saúde pública. Todas as três representam oportunidades imprescindíveis para historiadores e alguns já estão se aproveitando não apenas de outra série de fontes primárias, mas de uma literatura secundária importantíssima em jornais e monografias especializadas. Conhecimentos acerca do meio ambiente e da ecologia já fazem parte do repertório de todo historiador. Mas a sensibilidade à biodiversidade por enquanto não está evidente quanto à geodiversidade. 
SULCANDO OS MARES: UM HISTORIADOR DO IMPÉRIO PORTUGUÊS...

Outra característica consiste nas oportunidades para superar barreiras, límites e linhas divisórias - alguns naturais, outros culturais e outros impostos por regentes de países, de regiões, de estados, e mesmo de reis e regentes de nações e estados europeus no percurso de quinhentos para diante - e salientar a sua porosidade. Escravos, ciganos, homens de negócio, padres e frades, soldados, famílias inteiras, artesãos atravessaram fronteiras, sem intenções maliciosas. Missionários, bispos, governadores, vice-reis e outros empregados da coroa ou da burocracia faziam parte de uma movimentação humana entre o Oriente, a África e a América, adaptando-se às novas condições, novos contextos, e novos desafios e oportunidades. Frequentemente, tais obstáculos foram atribuíveis a atitudes sem fundamento, a percepções erradas, à santa ignorância ou a tradições passadas de uma geração para a seguinte e aceitas sem questão. O Brasil teve um impacto não apenas por toda a bacia do Atlântico e continentes à orla do oceano, mas global: disseminaão de plantas; disseminação de diamantes e de ouro; e disseminação de produtos agrícolas. Igualmente, foi receptor de plantas da Europa, da África, e da Ásia e descarregavam-se nos seus portos produtos das quarto partes do mundo. Em todos estes casos, houve uma dimensão não apenas comercial, mas também cultural.

Há uma gama de tópicos que exigem a atenção daqueles historiadores interessados na história do Atlântico Luso-afrobrasileiro: centros urbanos como núcleos de multiculturalismo e pontos de convergência; o status sui generis de portos como pontos de encontro entre o continente e o oceano e como eixos nos movimentos de pessoas e mercadorias, e do intercâmbio de informações; um estudo social e multicultural da variedade de portos (fluviais, e aqueles na orla atlântica e praticando a cabotagem em contra-distinção àqueles com horizontes oceânicos e transoceânicos); as histórias e as dimensões culturais de plantas, sobretudo daquelas que foram comercializadas: cana de acúcar, fumo, algodão, arroz, cacau; a transferência de conhecimentos tecnológicos de ameríndios (a preparação de mandioca, e de drogas do sertão, inclusive cacao 
e baunilha) ou de africanos (cultivo de arroz, conhecimentos metalúrgicos e de mineração) para os Portugueses; os modos de produção não apenas foram caracterizados por uma dimensão multiétnica com base na mão de obra, em uma mistura de tradições e na tecnologia, mas o próprio produto - como fumo e ouro e açúcar - assumiu o papel de ser o instrumento que, pela sua comercialização e divulgação, criou um vínculo entre grupos e regiões bem distintos em vários continentes; sobre os tropeiros, que atravessaram o Brasil, do sul até ao norte, do litoral para os sertões, chegaram a ter uma perspetiva ampla da colônia e dos seus habitantes, além de desempenhar um papel importantíssimo na economia também como portadores de cartas, mensagens e notícias; numa outra forma de descentralização, estudos que tratam do "faroeste" como o centro, e adotam uma perspectiva olhando para o Atlântico; a oportunidade oferecida pelo estudo do Rio Paraguaia como ponto de encontro de representantes dos impérios americanos espanhóis e portugueses e as interações através e ao longo do rio utilizando os arquivos em Sucre; a violência (nas suas várias manifestações em terra e no mar) como realidade em todas as camadas sociais; a presença no Congo e no Brasil de uma igreja afro-Católica; os cientistas brasileiros que contribuíram para os conhecimentos das ciências naturais no Brasil e a sua interação comos seus contemporâneos portugueses que também participaram nas "Viagens filosóficas" na África; e a cultura dos indivíduos de ascendência portuguesa mas nascidos no ultramar (os crioulos "brancos"); e, adotando uma posição contrária, um estudo sobre a estabilidade e falta de interação neste mundo atlântico luso-afro-brasileiro, quer dizer aqueles indivíduos que nunca saíram dos lugares onde nasceram, e aqueles capitães de navios que sulcaram as mesmas rotas marítimas dia sim dia não, ou seguiram um circuito sem interagir com outros circuitos; a cultura juridical, o direito consuetudinário e os preceitos tradicionais na América e na África portuguesas; os movimentos migratórios de europeus para o Brasil, dos retornados para Portugal, e um estudo tomando como pontos de referência uma cidade portuária em Portugal e outra no Brasil; e, finalmente, um 
SULCANDO OS MARES: UM HISTORIADOR DO IMPÉRIO PORTUGUÊS...

estudo que eu gostaria de ler intitulado "A Odisséia Atlântica de João Fernandes Vieira".

\section{Conclusão}

Assim termina esta fase da minha Odisséia pela "Atlantic History". Tenho certas reservas com relação a alguns aspectos deste exercício. Uma reside na noção de um Atlântico como um ponto de referência exclusivo. $O$ ver este oceano apenas como uma extensão de água diminui a sua importância que transcendeu as suas próprias orlas para ter impacto e exercer influência em terra, e mesmo em regiões cercadas de terra na Europa, na África e na América e sem acesso direto ao mar. Além disso, considerar o Atlântico como uma entidade em si mesmo é ignorar a realidade de ele constituir parte de uma continuidade oceânica que incorpora todos os oceanos do mundo. As rotas, as pessoas, as culturas, as mercadorias, e os produtos do Atlântico mantiveram um constante intercâmbio com outros oceanos e contribuíram, tanto como receptores tanto como transmissores, à interligação global de comércio, mobilidade humana, e de culturas na época moderna.

Uma outra reserva minha é a respeito de uma historiografia que, à primeira vista, não apenas admita mas mesmo faz questão de escapar-se de um contexto imperial. Em geral, a história do Atlântico português, não apenas do hemisfério norte, mas igualmente do hemisfério sul, é uma história que não pode ser contada em isolamento mas em relação a outros impérios, sejam europeus ou africanos, e mesmo orientais. Uma característica da coroa portuguesa no governo do ultramar foi adotar um modus operandi altamente consultativo. Esta dimensão não tem tido a atenção que merece, sobretudo nas nossas considerações a respeito da "Atlantic History". Qualquer pesquisador nos arquivos não deixa de ser consciente dos esforços da parte do próprio rei e dos seus representantes de 
identificar o cerne de um problema, de uma petição, de um protesto, ou de uma situação capaz de ameaçar a "boa ordem da república" e o "bem comum". Em seguida, foi iniciada uma série de consultas com o fim de conseguir todos os fatos relevantes. Este processo podia exigir a participação de conselheirios do rei e pedidos de opinióes e pareceres da parte dos membros da Casa da Consciência e Ordens e outros conselhos na metrópole. Cartas pedindo informações foram despedidas a vice-reis, governadores, capitães de fortalezas, bispos e outras dignidades eclesiásticas no ultramar. Este processo estendeu-se ao nível regional e mesmo paroquial: juízes ordinários e vereadores de um Senado da Câmara; provedor e mesários de uma Santa Casa de Misericórdia; o prior de uma Ordem Terceira; pessoas notáveis, "nobres da terra" e "poderosos do sertão"; padres paroquiais e familiares da Inquisição. Uma decisão, baseada neste montão de dados e pareceres, foi feita pelo rei em consulta com os seus conselheiros. Este processo minucioso foi capaz de resolver o caso satisfatoriamente, mas também capaz de fracassar. Representantes da coroa no ultramar reclamaram que tais decisões podiam ser prejudiciais ao processo jurídico e diminuir a sua autoridade e que informações fossem falsificadas ou estivessem sem credibilidade.

Mesmo relegando para um segundo plano uma perspetiva metropolitana ou imperial, é inegável o papel importante desempenhado pelos reis de Portugal. Foi um rei a corporificação de todos os atributos associados com um reino ou um império, do poder indivísel e da centralização do governo e da administração. No tocante às políticas e práticas de governo ligadas ao Atlântico, os reis tiveram que pesar benefícios comerciais, interesses políticos e relações diplomáticas, inter alia. Vamos considerer alguns exemplos tirados à toa. Estes manifestam como a personagem do rei não pode ficar ausente de "Atlantic History" mas admite a possibilidade da narrativa não revolver ao redor dele como protagonista central. Vamos considerar alguns exemplos da intervenção real ou de decisões da coroa que impactaram na história do Atlântico de falar português. Alguns foram de ordem diplomática: os Tratados de 
SULCANDO OS MARES: UM HISTORIADOR DO IMPÉRIO PORTUGUÊS...

Methuen; como responder a uma proposta do rei de Daomé para inaugurar um comércio mais intensivo entre o seu reino e o Brasil, levando em conta que uma resposta favorável podia levar à concessão de terras para um forte e uma feitoria. Outros foram de ordem operacional e comercial: autorizar ou não viagens transatlânticas por navios individuais ou insistir em frotas ou comboios que oferecessem mais segurança; promover ou não companhias privadas comercias, sobretudo para a África ocidental; restrições e mesmo proibições de embarcações da carreira da India ou de outras, dependendo do porto de origem, fazer escala em portos da África ocidental, ou das Ilhas. Houve outros de ordem administrativa: a reformulação da capitania do Rio de Janeiro que levou a sua configuração definitiva em 1709, a criação de novas capitanias de São Paulo e Minas Gerais, e uma nova onda de reformas levando a uma nova configuração de São Paulo resultante da perda dos seus territórios para o oeste com a criação (1748) das capitanias de Goiás e Mato Grosso. Em tais casos, não foi apenas a perda de espaços territoriais, mas também, ainda mais sensível para os colonos, a percebida injúria em termos de jurisdição e orgulho regional, sentimentos compartilhados igualmente por governadores (sobretudo do Rio de Janeiro e de São Paulo) cujo poder e autoridade ficaram diminuídos. A criação do Distrito Diamantino, uma colônia dentro de uma colônia, isenta da jurisdição do governador de Minas Gerais, e cujo administrador responsável era apenas o rei foi o caso mais extremo de intervenção régia no hemisfério sul. $\mathrm{Da}$ outra orla do Atlântico, a nomeação de um governador em Benguela num esforço de melhorar a administração daquela região, promover exploração de terras minerais e abrir caminho trans-Africano para Moçambique fracassou. Tais decisões régias, ordens régias e alvarás com força de lei exerceram um impacto que ultrapassou as dimensões exclusivamente diplomáticas, comerciais, operacionais, e administrativas. Tiveram repercussões sociais, culturais, políticas, econômicas, em indivíduos de várias etnias no Brasil e na África e mesmo no próprio Portugal. E não vou falar aqui da pletora de ordens, de alvarás, de cartas com força de lei, de correspondência entre o 
rei ou o Conselho Ultramarino com vice-reis, governadores, ouvidores, bispos e vereadores, e que trataram exclusivamente de circumstâncias de ordem social e cujo teor penetrou até aos interstícios da sociedade colonial, tocando na vida cotidiana de todos sem fazer distinção. Aquí, é relevante notar que existiu uma válvula de escape: quer dizer, tais ordens e intenções régias eram susceptíveis a serem interpretadas, negociadas e adaptadas para ter em conta as condições locais no ultramar e mesmo condenadas ao oblívio, nunca abertas e perdidas em montes de papel caracterizados por um empregado da coroa nos fins do século dezoito como uma "Babel tão confusa".

No que diz respeito à "Atlantic History", a "nova história imperial" ou mesmo "uma nova história imperial", há dúvidas ainda a serem resolvidas, e problemas a enfrentar, para chegar a um equilíbrio entre várias perspectivas em competição e, concorrentemente, um tratamento que seja justo, equitativo, e proporcional à importância de um assunto em relação a outros assuntos. A meu ver, seja como for a caracterização de "escolas" de historiadores, no fim das contas, o exercício de historiador(a) hoje em dia tem aspectos em comum com um astrônomo: a paralaxe. O Dicionário Houaiss da língua portuguesa (Rio de Janeiro: Objetiva, 2004) oferece (entre outras) duas definições de paralaxe que acho relevante a meu argumento: "deslocamento aparente de um objeto quando se muda o ponto de observação"; e "aparente deslocamento angular de um corpo celeste devido ao fato de estar sendo observado a partir da superfície e não do centro da Terra ou por estar sendo observado a partir da Terra e não do Sol". Os nossos conhecimentos do universo, da humanidade, e das forças naturais têm criado um banco de dados tão rico que oferece uma oportunidade para cada estudioso escolher o caminho mais apropriado às suas habilidades, recursos e interesses, e para aproveitar-se de uma variedade de perspectivas e aproximações, cada uma das quais tem valor. A escolha exige do historiador os atributos de um juiz capaz de identificar os aspectos decisivos de um caso, atribuir um peso em comparação aos outros e tomar decisões judiciárias salomônicas. Para chegar a uma conclusão satisfatória exige 
SULCANDO OS MARES: UM HISTORIADOR DO IMPÉRIO PORTUGUÊS...

também os atributos e a habilidade de um malabarista, o temperamento, poder de concentração e os nervos de aço de um acrobata. Em fim de contas, achei a experiência de tratar da "Atlantic History" intelectualmente estimulante e que o investimento de energia e de tempo foi amplamente compensado pelo viajar por novos caminhos e contemplar novos horizontes de vários pontos de observação.

\section{Agradecimentos}

Agradeço a Professora Marisa Saenz Leme, coordenadora do Programa de Pós-Graduação em História, pelo seu convite para proferir uma Aula Magna na Universidade de São PauloFranca, uma comunicação que se tornou em aula inaugural do novo campus. Agradeço também a Professora Denise A. Soares de Moura, coordenadora do Centro de Documentação e Apoio à Pesquisa Histórica, da mesma universidade que facilitou um encontro informal com os seus orientandos e um estimulante intercâmbio de idéias sobre assuntos históricos. Na preparação deste texto em português, contei com a assistência do Professor Amilcar Araújo Pereira e da Professora Denise Moura. O texto beneficiou da atenção meticulosa do revisor ortográfico o Professor Sergio Drummond Madureira Carvalho. O casal Jean Marcel Carvalho Franca e Susani Silveira Lemos França contribuíram ao fato dessa minha visita ser inesquecível.

Agradeço ao Oxford University Press por autorizar a publicação da tradução em português de um trecho de um texto que deve ser publicado num volume intitulado The Oxford Handbook of the Atlantic World, c. 1450-c.1820, organizado por Nicholas Canny e Philip Morgan. 
RUSSELL-WOOD, A.J.R. Crossing the seas: A historian of the Portuguese Empire comes face to face with the "Atlantic History". História, v.28, n.1, p.17-70, 2009.

\begin{abstract}
This contribution to history has two dimensions of which one predominates, being the historiography: the genesis and evolution of the "Atlantic History", its characteristics, emphases and methodology, and how it diverges from the conscious history of an imperial framework. The second is a practicum: that is to say, my attempt in conceptualizing and organizing an article about the "Luso-Afro-Brazilian Atlantic" in the period around 1660 up to around 1760" according to what is understood as the guidelines and precepts of the "Atlantic History". From the fruit of such experiences, I conclude with an evaluation of the pros and cons of the "Atlantic History", in comparison with other historiographies, and make observations with respect to its potential to open up new lines of research into Brazilian colonial history.
\end{abstract}

Keywords: Historiography; Luso-Afro-Brazilian Atlantic; Atlantic History.

\title{
NOTAS
}

1 O meu incentivo para escrever Um mundo em movimento: os Portugueses na África, Asia, e América, 1415-1825 (Lisboa: Difel, 1998) foi oferecer uma alternativa mais abrangente que incorporava os hemisférios este e oeste e a presença portuguesa nos quatro continentes.

${ }^{2}$ Philip D. Morgan e Jack P. Greene, "Introduction: The Present State of Atlantic History", em Atlantic History: A Critical Appraisal. Orgs. Jack P. Greene e Philip D. Morgan (Oxford: Oxford University Press, 2009), pp. 3-5. Para uma perspectiva histórica mais ampla, consulte Bernard Bailyn, Atlantic History. Concept and Contours (Cambridge, EUA, e Londres: Harvard University Press, 2005), pp. 3-56.

${ }^{3}$ Bernard Bailyn, "The Idea of Atlantic History", Itinerario, 20 (1996): 19-44. 
SULCANDO OS MARES: UM HISTORIADOR DO IMPÉRIO PORTUGUÊS...

${ }^{4}$ Jack P. Greene, "Introduction: The Present State of Atlantic History", p. 3. A tradução é minha.

${ }^{5}$ John Elliott, "Afterward: Atlantic History: A Circumnavigation", em The British Atlantic World, 1500-1800. Orgs. David Armitage e Michael J. Braddick(New York: Palgrave, 2002), p. 239.

${ }^{6}$ Bailey W. Diffie e George D. Winius, Foundations of the Portuguese Empire, 1415-1580 ( Minneapolis: University of Minnesota Press, 1977); Vitorino Magalhães Godinho, Os descobrimentos e a economia mundial. 4 vols. (Lisboa: Editorial Arcadia, 1963).

${ }^{7}$ Frédéric Mauro, Le Portugal et l'Atlantique au XVlle siècle, 1570-1670: étude économique (Paris: S.E.V.P.E.N., 1960).

8 Telmo Gomes, Portuguese Ships, $14^{\text {th }}-19^{\text {th }}$ Century (Lisboa: Edições INAPA, 1995).

9 Patrick O. Flanagan, Port Cities of Atlantic Iberia, c. 1500-1900 (Aldershot, Inglaterra; e Burlington, Vermont, EUA: Ashgate Publishing, 2008).

10 Hal Langfur, The Forbidden Lands. Colonial Identity, Frontier Violence, and the Persistence of Brazil's Eastern Indians, 1750-1830 (Stanford: Stanford University Press, 2006).

${ }_{11}$ A. J. R. Russell-Wood, Escravos e libertos no Brasil colonial (Rio de Janeiro: Civilização Brasileira, 2005),pp. 129-54, 324-28.

12 Joseph C. Miller, Way of Death. Merchant Capitalism and the Angolan Slave Trade,1730-1830 (Madison:University of Wisconsin Press1988), pp. 189-90, 242-43, 245-83.

13 Timothy J. Coates, Convicts and Orphans: Forced and StateSponsored Colonizers in the Portuguese Empire, 1550-1755 (Stanford: Stanford University Press, 2001).

14 José Gonçalves Salvador, Os Cristãos-Novos e o Comércio no Atlântico Meridional (São Paulo: Livraria Pioneira/Editora/MEC, 1978).

15 Michael Gomez, Black Crescent: The Experience and Legacy of African Muslims in the Americas (Cambridge: Cambridge University Press, 2005).

${ }^{16}$ Jean Boulègue, Les luso-africains de Sénégambie, XVle-XlXe siècles (Lisboa: 1989); Peter Mark, "Portuguese" Style and Luso-African Identity: Precolonial Senegambia, Sixteenth-Nineteenth Centuries (Bloomington: Indiana University Press, 2002); George E. Brooks, Eurafricans in Western Africa: Commerce, Social Status, Gender, and Religious Observance from the Sixteenth to the Eighteenth Century (Athens: Ohio University Press; e Oxford: James Currey, 2003). 
17 Barry Boubacar, La Sénégambie du XVe au XIXe siècle-Traite négrière, Islam et conquête coloniale (Paris: 1988); Senegambia and the Atlantic Slave Trade (Cambridge: Cambridge University Press, 1998).

${ }^{18}$ Laurent Vidal, Mazagão. La ville que traversa l'Atlantique. Du Maroc à l'Amazonie (1769-1783). (Aubier: Éditions Flammarion, 2005).

19 Alberto Vieira, Portugal y las islas del Atlántico (Madrid: Editorial Mapfre, 1992; Thomas Bentley Duncan, Atlantic Islands: Madeira, the Azores, and the Cape Verdes in Seventeenth-Century Commerce and Navigation (Chicago: University of Chicago Press, 1972).

20 José Manuel Azevedo e Silva, A Madeira e a construção do mundo Atlântico (séculos XV-XVll). (Funchal, 1995); David Hancock, Oceans of Wine: Madeira and the Organization of the Atlantic Market, 1640-1815 (New Haven:Yale University Press, 2008); A. H. de Oliveira Marques e João José Alves Dias, Atlas histórico de Portugal e do ultramar português (Lisboa: Centro de Estudos Históricos, 2003), mapas 314,315.

${ }^{21}$ Carlos A. Garcia, "A ilha de São Tomé como centro experimental do comportamento do luso nos trópicos", Studia, 19(dez., 1966), pp.209-22. 22 Joaquim Veríssimo Serrão, História de Portugal. A Restauração e a monarquia absoluta(1640-1750), 2a. edição (Lisboa: Editorial Verbo, 1977), tomo V, pp. 280-87; Exemplar é o micro-estudo de André Pinto de Sousa Dias Teixeira, A ilha de São Nicolau de Cabo Verde nos séculos XV e XVIll (Lisboa: Centro de História de Além-mar, Universidade Nova de Lisboa, 2004).

${ }^{23}$ A. H. de Oliveira Marques e João José Alves Dias, Atlas histórico de Portugal e do ultramar português (Lisboa: Centro de Estudos Históricos, 2003), mapas 318,319; Arlindo Manuel Caldeira, Mulheres, sexualidade e casamento em São Tomé e Príncipe (séculos XV-XVlll). 2a edição (Lisboa: Edições Cosmos, 1999); C. R. Boxer, The Church Militant and Iberian Expansion, 1440-1770(Baltimore: The Johns Hopkins University Press, 1978), pp.6-7.

${ }^{24}$ A. H. de Oliveira Marques e João José Alves Dias, Atlas histórico de Portugal e do ultramar português (Lisboa: Centro de Estudos Históricos, 2003), mapas 240, 241, 316, 317, 318.

25 António Carreira, "Tratos e resgates dos portugueses nos rios de Guiné e ilhas do Cabo Verde nos começos do século XVll", Revista de História Econômica e Social, 2 (jul-dez, 1978), pp. 91-103; e Carreira, Os portugueses nos rios de Guiné, 1500-1900 (Lisboa, 1984); George E. Brooks, "Cacheu: A Luso-African Entrepôt at the Nexus of the BiafadaSapi and Nabyun-Bak Trade Networks", em Mansas, escravos, grumetes e gentio: Cacheu na encruzilhada de civilizações, org. por 
SULCANDO OS MARES: UM HISTORIADOR DO IMPÉRIO PORTUGUÊS...

Carlos Lopes (Bissau: Instituto Nacional de Estudos e Pesquisa, 1993), pp. 175-95; Walter Hawthorne, Planting Rice and Harvesting Slaves: Transformations along the Guinea-Bissau Coast, 1400-1900 (Portsmouth, N.H.,: Heinemann,2003).

${ }^{26}$ David Birmingham, The Portuguese Conquest of Angola (Oxford: Oxford University Press, 1965) e, do mesmo autor, Trade and Conflict in Angola: the Mbundu and their Neighbours under the Influence of the Portuguese, 1483-1790 (Oxford: Oxford University Press, 1966); José Carlos Venâncio, A economia de Luanda e hinterland no século XVlll: Um estudo de sociologia histórica (Lisboa: Editorial Estampa, 1996); para uma dimensão internacional, consulte Phyllis M. Martin, The External Trade of the Loango Coast, 1576-1870: The Effects of Changing Commercial Relations on the Vili Kingdom of Loango (Oxford: Oxford University Press, 1972); Veja também Ray Kea, Settlements, Trade and Polities in the Seventeenth-Century Gold Coast (Baltimore: Johns Hopkins University Press, 2000).

${ }^{27}$ Joseph C. Miller, Way of Death, pp. 577-79 e 581-83.

${ }^{28}$ Oliveira Marques e João José Alves Dias, Atlas histórico de Portugal e do ultramar português, mapas 321,322.

${ }^{29}$ O império luso-brasileiro, 1620-1750, coordenação de Frédéric Mauro (Lisboa: Editorial Estampa, 1991); O império luso-brasileiro, 1750-1822, coordenação de Maria Beatriz Nizza da Silva (Lisboa: Editorial Estampa, 1986). Volumes Vll e Vlll respetivamente da Nova história da expansão portuguesa, direcção de Joel Serrão e A. H. de Oliveira Marques; Charles R. Boxer, A idade do ouro do Brasil (Dores de crescimento de uma sociedade colonial) (São Paulo: Companhia Editora Nacional, 1963); A.H. de Oliveira Marques e João José Alves Dias, Atlas histórico de Portugal e do ultramar português, mapas 330-336).

${ }^{30}$ A. J. R. Russell-Wood, "Ports of Colonial Brazil" em Franklin W. Knight e Peggy Liss, orgs., Atlantic Port Cities. Economy, Culture, and Society in the Atlantic World, 1650-1850. Knoxville: University of Tennessee Press, 1991), pp. 196-239; e Russell-Wood, "Centro e periferia no mundo luso-brasileiro, 1500-1808", Revista brasileira de história. No. 36, vol.18 (ANPUH, 1998):187-249.

${ }^{31}$ A. J.R. Russell-Wood, Escravos e libertos no Brasil colonial, pp.53-104, 157-187, 296-312; Mariana L. R. Dantas, Black Townsmen: Urban Slavery and Freedom in the Eighteenth-Century Americas (New York: Palgrave Macmillan, 2008), pp. 47-69, 97-125. 
32 João L. R. Fragoso, Homens de grossa aventura: acumulação e hierarquia na praça mercantil do Rio de Janeiro(1790-1830) (Rio de Janeiro:Arquivo Nacional, 1992).

${ }^{33}$ Pierre Verger, Flux et reflux de la traite des nègres entre le golfe de Bénin et Bahia de Todos os Santos du dix-septième au dix-neuvième siècle (Paris: Mouton, 1968. Tradução portuguesa, São Paulo, 1987).

${ }^{34}$ José C. Curto, Enslaving Spirits: The Portuguese-Brazilian Alcohol Trade at Luanda and its Hinterland, c. 1550-1830(Leiden e Boston: Brill, 2004); Jean-Baptiste Nardi, O fumo brasileiro no período colonial. Lavoura, comércio, e administração (São Paulo:Editora Brasiliense, 1996). Veja também: Stanley J. Alpern, "What Africans Got for their Slaves: A Master List of European Trade Goods", History in Africa, 22 (1995), pag.5-43.

${ }^{35}$ James H. Sweet, Recreating Africa: Culture, Kinship, and Religion in the Afro-Brazilian World, 1441-1770 (Chapel Hill and Londres: University of North Carolina Press, 2003);António Brásio, "O problema da eleição e coroação dos reis do Congo", Revista Portuguesa de História, t. Xll,vol. 1(1969),: 351-81; Mary Karasch, "Central Africans in Central Brazil, 1780-1835", e Elizabeth W. Kiddy, "Who is the King of Kongo? A New Look at African and Afro-Brazilian Kings in Brazil", ambos em Linda M. Heywood, org., Central Africans and Cultural Transformations in the African Diaspora (Cambridge e New York: Cambridge University Press, 2002).

${ }^{36}$ John K. Thornton, The Kongolese Saint Anthony. Dona Beatriz Kimpa Vita and the Antonian Movement, 1684-1706 (Cambridge: Cambridge University Press, 1998); Luiz Mott, Rosa Egipciaca. Uma santa Africana no Brasil (Rio de Janeiro: Bertrand do Brasil, 1993).

${ }^{37}$ Silvia Hunold Lara, Fragmentos setecentistas. Escravidão, cultura e poder na América portuguesa (Sao Paulo:Companhia das Letras, 2007).pp. 173-218.

${ }^{38}$ A. J. R. Russell-Wood, "A projeção da Bahia no império ultramarino português", IV Congresso de História da Bahia. Anais. Vol. 1 (Salvador: Instituto Geográfico e Histoórico da Bahia e a Fundação Gregório de Matos, 2001), pp. 81-122;Corcino Medeiros dos Santos, "Relações de Angola com o Rio de Janeiro, 1736-1808", Estudos Históricos, 12 (1973), 7-68.

${ }^{39}$ Maria Beatriz Nizza da Silva, D. João $V$ (Lisboa: Círculo de Leitores/ Centro de Estudos dos Povos e Culturas de Expressão Portuguesa da Universidade Católica Portuguesa, 2006), pp. 89-119; Russell-Wood, "Portugal and the World during the Reign of Dom João V", em The Age 
SULCANDO OS MARES: UM HISTORIADOR DO IMPÉRIO PORTUGUÊS...

of the Baroque in Porrtugal, org. Jay Levenson (National Gallery, Washington, e Yale University Press, 1993), pp. 15-29.

40 Kenneth Maxwell, "The Atlantic in the Eighteenth Century: A Southern Perspective on the Need to Return to the 'Big Picture' ", Transactions of the Royal Historical Society, 6a serie, no. 3 (1993), pp. 209-236.

${ }^{41}$ Kenneth Maxwell, O Marquês de Pombal. Tradução de Saul Barata. Lisboa: Editorial Presença, 2001), pp. 68-89, 111-179.

${ }^{42}$ Este meu argumento está baseada numa leitura do quarto volume da História de Portugal, Direcção de José Mattoso, dedicado ao Antigo Regime(1620-1807), e coordenado por António Manuel Hespanha (Lisboa: Círculo de Leitores, 1993).

43 A. J. R. Russell-Wood, "Portuguese Literature" em The Oxford Encyclopedia of Maritime History, org. John Hattendorf. (Oxford: Oxford University Press, 2003), tomo 3, pp. 358-365; e, do mesmo autor, Portugal e o Mar: Um Mundo Entrelaçado (Lisboa: Assirio e Alvim, 1997).

${ }^{44}$ Amy Turner Bushnell, "Indigenous America and the Limits of the Atlantic World", em Greene e Morgan, Atlantic History, p. 191, e Philip D. Morgan, "Africa and the Atlantic, c. 1450-c. 1820", p.223.

45 José Jobson de Andrade Arruda, "O Império Tripolar: Portugal, Angola, Brasil", em O Brasil no Império marítimo português. Orgs. Stuart Schwartz e Erik Lars Myrup (Baurú: São Paulo: EDUSC. 2008), pp. 509-531.

${ }^{46}$ Luiz Felipe de Alencastro, O Trato dos Viventes. Formação do Brasil no Atlântico Sul (São Paulo: Companhia das Letras, 2000), p. 10.

${ }^{47}$ Daviken Studnicki-Gizbert, A Nation upon the Ocean Sea. Portugal's Atlantic Diaspora and the Crisis of the Spanish Empire, 1492-1640 (Oxford: Oxford University Press, 2007).

${ }^{48}$ Alida C. Metcalf, Go-Betweens and the Colonization of Brazil, 15001600 (Austin: University of Texas Press, 2005; Hal Langfur, The Forbidden Lands; e Ronaldo Vainfas, A heresia dos índios-Catolicismo e rebeldia no Brasil colonial (São Paulo, Companhia das Letras, 1995).

${ }^{49}$ M. Kittiya Lee, "The Arts of Proselytization: Music as Mediator of Jesuit-Amerindian Encounters in Early Colonial Brazil, 1549-1579", Leituras. Revista da Biblioteca Nacional, S 3, no, 6, (Abril-Outubro, 2000): 149-72; e "Conversing in Colony: The Brasílica and the Vulgar in 
A.J.R. RUSSELL-WOOD

Portuguese America, 1500-1759", tese de doutoramento, The Johns Hopkins University, 2005.

Artigo recebido em 05/2009. Aprovado em 07/2009. 